\title{
Ecological footprint and human well-being nexus: accounting for broad-based financial development, globalization, and natural resources in the Next-11 countries
}

\author{
Solomon Prince Nathaniel ${ }^{1,2^{*}}$ (1)
}

\begin{abstract}
The Next-11 (N11) countries have witnessed great advancements in economic activities in the past few years. However, the simultaneous attainment of environmental sustainability and improved human well-being has remained elusive. This study probes into ecological footprint (EF) and human well-being nexus in N11 countries by applying advanced estimation techniques compatible with heterogeneity, endogeneity, and cross-sectional dependence across country groups. From the findings, human well-being, captured by the human development index, increases the EF, and $\mathrm{EF}$ also increases human well-being which suggests a strong trade-off between both indicators. This shows that policies that are channeled toward promoting human well-being are not in consonance with environmental wellness. Financial development and biocapacity increase the $E F$, while natural resources and globalization reduce it. Human well-being increases the EF in all the countries except in Egypt. This study argues that strong institutions could help mitigate the trade-offs and ease the simultaneous attainment of both environmental preservation and improved human well-being. The limitations of the study, as well as, possible directions for future research are discussed.
\end{abstract}

Keywords: Human well-being, Globalization, Ecological footprint, Financial development, Sustainable development, $A M G$

\section{Introduction}

Environmental matters are now a serious issue and are gaining more popularity by the passing of each day. But, the challenge of maintaining a sustainable environment without inhibiting human well-being is still ubiquitous. Many factors have been found culpable of environmental degradation, but the human factor, is most often than not, ignored. However, human factors are the major drivers of ecological distortions [42, 43, 52, 53]. The link between ecological conditions and human wellbeing cannot be overemphasized. Better environmental

\footnotetext{
*Correspondence: nathaniel_solomon21@yahoo.com

1 Department of Economics, University of Lagos, Akoka, Nigeria

Full list of author information is available at the end of the article
}

management, could, in principle, come with lots of good outcomes for humanity, with a positive synergy between human well-being and environmental conditions [41]. A positive synergy between human well-being and environmental quality is quite ideal and desirable, but it would be erroneous to believe that both are, or should be mutually reinforcing. A trade-off is expected especially in a situation where environmental and growth policies are not well-designed [75]. It is most likely that variables/factors like urbanization, globalization, energy consumption, and natural resources exploration can promote ecological distortions and increase the demands for health, food, education, and wealth which are core human development elements $[2,5,6,44,47,54,72]$. 
The United Nations rolled out the Sustainable Development Goals (SDGs) in 2015 and listed; Quality Education (Goal 4), No Poverty (Goal 1), Climate Action (Goal 13), Good Health and Well-Being (Goal 3), Zero Hunger (Goal 2), Reduced Inequality (Goal 10), Life on Land (Goal 15), etc., as some of the tenets of the SDGs. The idea behind these goals is to improve human well-being and place humans at a level where they can efficiently contribute to environmental wellness. However, the improvement of human well-being in some of the N11 countries is still in a pitiable state. Also, the simultaneous attainment of Goal 3 and Goal 15 still remains elusive.

Though these countries (N11) have witnessed persistent growth in their GDP over the years, there are still some key issues capable of declining human well-being that is yet to be appropriately addressed. As such, the Human Development Index (HDI) of these countries has witnessed little or no improvement. See Table 1.

Table 1 reveals that all the countries have their EF higher than their BIO, inferring ecological deficit. Korea has the highest HDI, and also the worst environmental records, as the country's EF is exceedingly higher than its BIO. A closer look at Table 1 reveals that each country has witnessed an increase in its HDI between the time periods. The questions begging for answers remain; is there a trade-off between human well-being and environmental quality in the N11 countries? Does the drain in biocapacity, or drench in EF influence human wellbeing in the N11 countries? What is the influence of globalization on human well-being in the N11 countries? This study will assist policymakers in these countries to align their objectives of improving human well-being and the quality of life, with that of preserving the natural ecosystems.
Attaining human well-being without deteriorating environmental quality is required in N11 countries. A better understanding of how both are connected is of utmost importance in these countries. This knowledge will inform a desirable human well-being development plan that will enhance sustainable growth and maintain environmental quality. This study is super useful for the N11 countries where factors like globalization, economic growth, urbanization, financial development, and other socio-economic conditions are depleting the biocapacity, causing resource depletion, and increasing the regions ecological footprint (EF). Of little wonder, all the N11 countries are now occupying an ecological deficit territory. Figure 1 presents the study framework.

Energy consumption, natural resources exploration, and financial development may have consequences on the quality of the environment [16]. Financial development instigates higher loan disbursement to customers at low costs. This access to funding gives the firm the opportunity to create demand for their outputs thereby promoting industrialization [86]. Industrialization stimulates urbanization and energy consumption which gives room for ambient air pollution. Also, air pollution hampers human well-being by creating sickness, infant mortality, and other health defects [51]. At the early stage of financial development, emissions level is expected to rise. However, as financial development persists, emissions decline since the former promotes energy innovations, which might result in energy generation from cleaner sources [86, 87].

This study contributes from the following angles: (1) this is the pioneer study to examine the influence of biocapacity, EF, and financial development on human well-being in the N11 countries. (2) This study employs

Table 1 Biocapacity, ecological footprint, and HDI in the N11 countries. Sources Global Footprint Network [25] and UNDP [76]

\begin{tabular}{|c|c|c|c|c|c|c|c|c|c|}
\hline \multirow[t]{2}{*}{ Countries } & \multicolumn{3}{|c|}{2014} & \multicolumn{3}{|c|}{2015} & \multicolumn{3}{|c|}{2016} \\
\hline & $\mathrm{EF}$ & $\mathrm{BIO}$ & HDI & $\mathrm{EF}$ & $\mathrm{BIO}$ & HDI & $\mathrm{EF}$ & BIO & $\mathrm{HDI}$ \\
\hline Bangladesh & 0.80 & 0.40 & 0.57 & 0.87 & 0.40 & 0.58 & 0.84 & 0.40 & 0.59 \\
\hline Egypt & 1.96 & 0.45 & 0.68 & 1.91 & 0.45 & 0.69 & 1.81 & 0.44 & 0.69 \\
\hline Indonesia & 1.68 & 1.26 & 0.69 & 1.63 & 1.27 & 0.69 & 1.68 & 1.22 & 0.70 \\
\hline Iran & 3.34 & 0.74 & 0.78 & 3.23 & 0.75 & 0.78 & 3.19 & 0.73 & 0.79 \\
\hline South Korea & 5.73 & 0.67 & 0.89 & 5.85 & 0.67 & 0.89 & 6.00 & 0.66 & 0.90 \\
\hline Mexico & 2.57 & 1.20 & 0.75 & 2.56 & 1.16 & 0.75 & 2.60 & 1.17 & 0.76 \\
\hline Nigeria & 1.17 & 0.70 & 0.52 & 1.13 & 0.70 & 0.52 & 1.08 & 0.68 & 0.52 \\
\hline Pakistan & 0.82 & 0.38 & 0.54 & 0.81 & 0.36 & 0.55 & 0.83 & 0.36 & 0.55 \\
\hline Philippines & 1.09 & 0.57 & 0.69 & 1.15 & 0.56 & 0.70 & 1.32 & 0.54 & 0.70 \\
\hline Turkey & 3.25 & 1.44 & 0.79 & 3.34 & 1.50 & 0.80 & 3.35 & 1.43 & 0.80 \\
\hline Vietnam & 1.78 & 1.02 & 0.67 & 2.01 & 1.05 & 0.68 & 2.12 & 1.01 & 0.68 \\
\hline
\end{tabular}

BIO biocapacity 


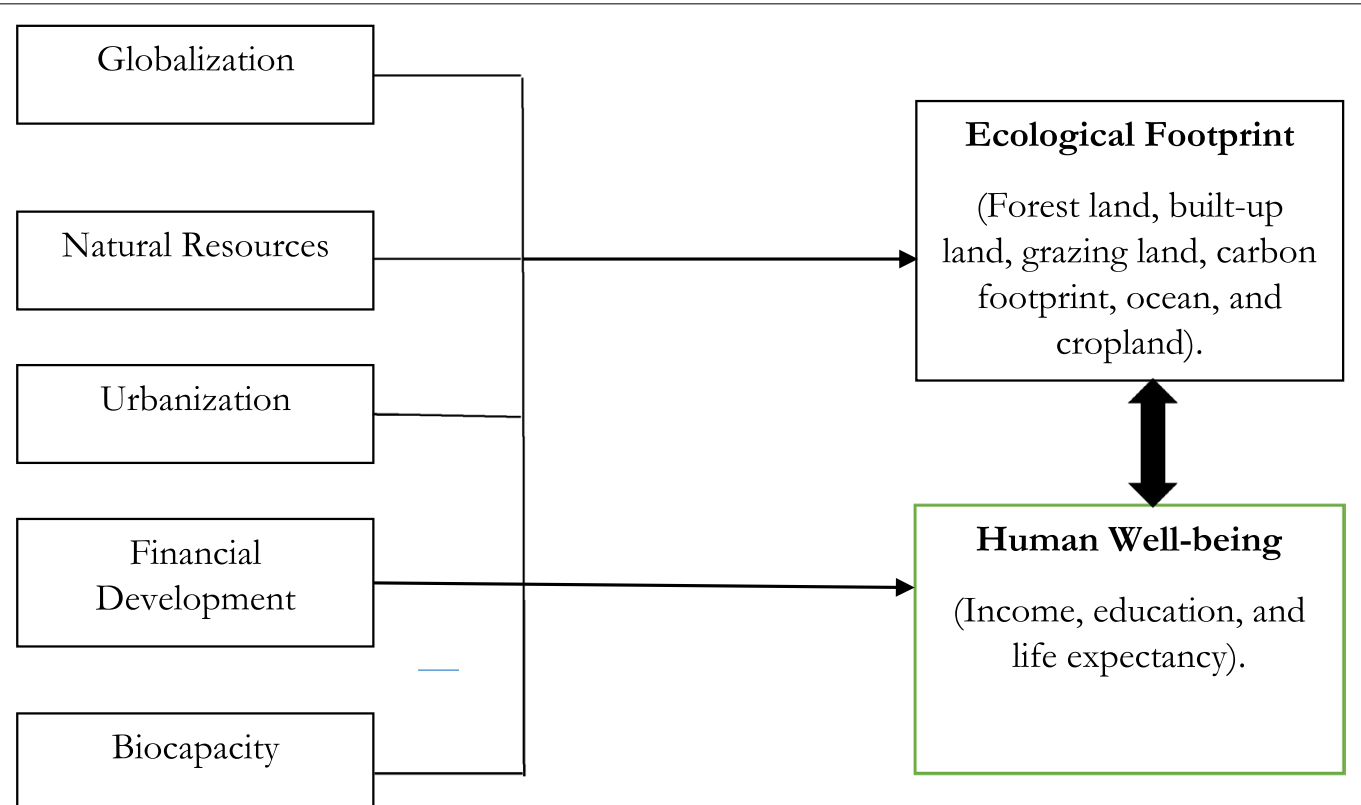

Fig. 1 Study framework

a positive and comprehensive environmental indicator (EF) that accommodates forest land, built-up land, grazing land, carbon footprint, ocean, and cropland. Furthermore, second-generation econometric techniques have been employed to address heterogeneity, endogeneity, and CD. (3) The augmented mean group (AMG) estimator, Driscoll-Kraay (DK), Panel-corrected standard error (PCSE), and the cross-sectionally augmented autoregressive distributed lag (CS-ARDL) model approach are applied to achieve robust estimates which can inform policy formulation that will enhance environmental sustainability and the improvement of human well-being in general, and N11 countries in particular.

This study is arranged thus: "Literature review" section presents the literature, and "Methodology, model, and data source" section addresses the methodology and data source. Results are presented and discussed in "Results" section. "Conclusions" section concludes.

\section{Literature review}

\section{Theoretical background/underpinning}

Gross domestic product (GDP) has been widely used as a measure of economic wellness. The GDP is just the monetary value of goods and services produced within a country, usually for 1 year. This metric (GDP) has its limitations as it fails to capture human welfare, health impairment, and education relating to environmental awareness [17]. The intuition here is clear; there is a need for an all-embracing metric that addresses welfare effects, accounts for society's education, income, and health in the environmental quality-welfare debate. For this reason, the HDI meets our demand. There are studies in the literature that support a positive association between education and life expectancy (both components of HDI) and environmental disasters but failed to establish the same association between the aforementioned variables and GDP [13].

The EF is a relatively new concept, and it appears that only a few studies have used this tool to measure human well-being activities impact the environment. As such, limited research has been completed on human wellbeing as it relates to environmental sustainability. Theoretically, studies in the past have tried to develop an index that addresses social-economic and environmental difficulties (see, for instance, [12]). The two theories that evolve from such integrated sustainable HDI are the win-win and the trade-off approach. The win-win approach believes society/community can achieve double benefits of improved environmental quality and wellbeing, while the trade-off approach argued that both are not self-enforcing that a trade-off is inevitable. This study intends to examine both approaches for the N11 countries with EF as the environmental indicator and HDI as the human well-being indicator. The EF measures mankind's demand for the regenerative capacity of our planet: Earth's biocapacity [21]. Apart from being an accounting tool, the EF is an area-based indicator that measures the intensity by which humans use resources and generate waste, relative to that area's capacity to provide for these activities. It is also referred to as "appropriated carrying 
capacity" since every person appropriates the productive capacity of nature $[15,23]$. It is expected that the outcome of this study will give insight and propose policy directions that will balance these two targets (human well-being and environmental wellness) simultaneously in the N11 countries.

\section{$\mathrm{HDI}$, globalization, biocapacity, and ecological footprint}

Most recent studies have tried to link HDI/human development to economic growth and financial development (see, $[26,73]$ ). However, the possibility abounds that HDI can also impact the EF. Environmental pollution and a fragile ecological environment impairs human well-being and health and causes ecological distortions $[11,89]$. Environmental degradation affects human wellbeing adversely and inhibits ecological balance. Also, the desire to improve the quality of life exacts pressure on the natural environment which in turn reduces the bio-productive land. Ahmed et al. [7] examined if human capital reduces the EF in G7 countries. The outcome was in the affirmative. The authors further noted that the level of human development matters for environmental wellness. Zafar et al. [85] explored the impact of human capital on the EF in the USA for the period 1970-2015 through the ARDL approach. Their findings suggest human capital that reduces the EF. Ahmed et al. [4] used the same approach as Zafar et al. [85] and also discovered a similar relationship between human capital and EF in China. Kassouri and Altıntaş [31] discovered that biocapacity and globalization reduce the EF after applying the Interactive Fixed Effects estimator on a panel of 13 MENA countries.

There are studies that have tried to link globalization with environmental quality. Shahbaz et al. [67] used the GMM technique to examine the influence of institution, globalization, and trade on the environment in the G7 countries from 1980 to 2014. They discovered that globalization harms the environment. In a similar gesture, Liu et al. [39] explored the effect of renewable energy and globalization on the quality of the environment in G7 countries between 1970 and 2015. From their findings, renewable energy adds to environmental quality, while globalization promotes pollution. Acheampong et al. [1] arrived at a similar result as regards the devastating impact of globalization on the environment in sub-Saharan Africa (SSA). The findings of Shahbaz et al. [67], Liu et al. [39], and Acheampong et al. [1] contradict the recent findings of Saud et al. [66] who discovered that globalization mitigated the EF in one-belt-one-road (OBOR) initiative countries.

Hassan et al. [27] used the ARDL approach to investigate the impact of biocapacity, human capital, and growth on the EF in Pakistan. Biocapacity and economic growth influence the environment negatively, while human capital declines the EF. Hassan et al. [28] further probed the influence of natural resource and biocapacity on the EF in Pakistan. The ARDL results revealed that biocapacity and natural resource increase EF. Also, causality flows from both variables to the EF. Pandey et al. [57] investigated the impact of biocapacity and globalization on the environment in Asia from 1971 to 2014. In contrast to the findings of Shahbaz et al. [67] and Acheampong et al. [1], they discovered that globalization promotes environmental quality, while biocapacity exacts a reverse influence on environmental quality.

\section{Financial development, urbanization, economic growth, and ecological footprint}

There is an on-going gradual transition from the use of $\mathrm{CO}_{2}$ emissions as an environmental indicator to $\mathrm{EF}$ in the cause of measuring the impact of financial development, urbanization, and economic growth on the environment. Zafar et al. [85] and Ahmed et al. [4] used the ARDL technique to investigate the impact of economic growth on the EF in the USA and China, respectively. Both studies agreed that economic growth increases the EF. Ahmed et al. [4] further reported that urbanization contributes to ecological pressure in China. Ahmed et al. [4] argued that urbanization in China is not sustainable and therefore called on policymakers to enact legislation that will enhance urban sustainability considering the population growth rate in China. Nathaniel et al. [49] investigated the interaction between economic growth, urbanization, and EF in CIVETS nations. The AMG estimator was employed. Long-run interaction was found among the variables. Economic growth decreases environmental deterioration, while urbanization increases it in CIVETS countries. Nathaniel et al. [50] studied the effect of urbanization on the EF in the MENA nations. They adopted the AMG algorithm for their study. The result indicated that urbanization and economic growth add to environmental deterioration. Further findings affirmed a one-way directional causality from urbanization and economic growth to the EF in MENA nations.

Saud et al. [66] applied the PMG approach to investigate the impact of globalization and financial development on the EF in OBOR countries from 1990 to 2014. Their findings affirmed that financial development increases the EF, while globalization reduces it. Ansari et al. [9] investigated the impact of economic growth on material footprint and EF in 37 Asian countries from 1991 to 2017 using the PMG, GMM, and DOLS techniques. Their findings showed that economic growth increases both indicators (material footprint and EF). Sharif et al. [68] also discovered that economic growth drives the EF in Turkey. Kassouri and Altıntaş [31] 
explored the effect of financial development and urbanization on EF in MENA countries. They discovered that both variables increase EF, but exact the opposite influence on human well-being.

In conclusion, the literature survey reveals that studies seldom examine the effects of HDI on EF. More so, there is no single study that has investigated the impact of HDI on the EF in N11 countries. The recently introduced financial development index by the IMF has never been used for any analysis that involves the N11 countries. This is the only study that tried to examine the existence of the win-win or trade-off hypothesis in N11 countries. The effect of urbanization, financial development, and globalization on the EF is still murky as consistency in findings remains elusive.

\section{Methodology, model and data source Methods}

This study adopts econometric procedures that are consistent with the properties of the data used in the study. A wrong procedure will yield bias and inconsistent estimates. To avoid such outcomes, this study proceeds with the $\mathrm{CD}$ test.

\section{Cross-sectional dependence}

As earlier mentioned, results could be biased if $C D$ is ignored. Earlier studies failed to consider the possibility of $\mathrm{CD}$ in their empirical analysis; knowing fully well that the world is now a global village where countries are closely knitted. CD is now common due to spillover effect, financial crisis, trade agreements, and international treaties, among others. As such, this study applies the $C D$ tests suggested by Pesaran [60] given as:

$$
C D=\sqrt{\frac{2 T}{N(N-1)}}\left(\sum_{i=0}^{N-1} \sum_{j=i+1}^{N-1} \rho i j\right) N(0,1)
$$

where $\rho i j=$ cross sections correlation of error between $i$ and $j . T$ is the time horizon, and $N$ represents cross sections. This study will be more concerned with the first two tests because they are robust in panels where $T$ (time dimension) $>N$ (cross section); which is the exact feature of our dataset.

\section{Unit root}

Apart from the $C D$ tests, the integration properties of the data are also necessary. The presence of $\mathrm{CD}$ will determine the choice of the unit root tests. Second-generation tests are preferred in the vicinity of $\mathrm{CD}$. Therefore, this study used the cross-sectionally augmented ADF (CADF) and cross-sectionally augmented IPS (CIPS) introduced by Pesaran [61]. Both tests account for CD and heterogeneity. Pesaran [61] suggested a Dickey-Fuller based tests (CADF) that is consistent with structural breaks, heterogeneity and $\mathrm{CD}$. The CADF test equation is given as:

$$
\Delta y_{i t}=\Delta \varphi_{i t}+\beta_{i} x_{i t-1}+\rho_{i} T+\sum_{j=1}^{n} \theta_{i j} \Delta x_{i, t-j}+\varepsilon_{i t}
$$

$\rho_{i}$ is the proxy of the unobservable common factor which Pesaran [61] introduced to eliminate CD emanating from common shocks that might affect all the units. Also, Pesaran [61] suggested a cross-sectional augmented version of the IPS test given as:

$$
\mathrm{CIPS}=\frac{1}{\mathrm{~N}} \sum_{\mathrm{j}=1}^{\mathrm{N}} \mathrm{CADF}_{\mathrm{t}}
$$

Both tests (CADF and CIPS) have unique properties. They can address serial correlation and perform better than all the first-generation tests.

\section{Cointegration}

When variables have the same order of integration, let us say, $I(1)$, it becomes necessary to ascertain if they have a long-run relation. The study applies the Westerlund [79] test to investigate the possibility of a cointegrating relationship among the variables. The test controls for $\mathrm{CD}$ and nuisance arising from endogeneity. It has a greater explanatory power compared to dynamic cointegration tests. Westerlund [79] constructed four statistics. Two of the four statistics are the group mean statistics,

$$
G_{\tau}=\frac{1}{N} \sum_{i=1}^{N} \frac{\widehat{\alpha_{i}}}{\operatorname{SE}\left(\widehat{\left.\alpha_{i}\right)}\right.} \text { and } \mathrm{G}_{\alpha}=\frac{1}{\mathrm{~N}} \sum_{\mathrm{i}=1}^{\mathrm{N}} \frac{\mathrm{T} \widehat{\alpha_{\mathrm{i}}}}{\widehat{\alpha_{\mathrm{i}}}(1)}
$$

which tests the cointegration of the whole panel, and the panel mean tests,

$$
P_{\tau}=\frac{\widehat{\alpha_{i}}}{\mathrm{SE}\left(\widehat{\left.\alpha_{i}\right)}\right.} \text { and } \mathrm{P}_{\alpha}=\mathrm{T} \widehat{\alpha}
$$

which examines the existence of cointegration in at least one of the units. The test applies bootstrap approach to account for $\mathrm{CD}$ and non-strictly exogenous regressors.

\section{Parameter estimation}

The current study adopted the AMG estimator of Bond and Eberhardt [14] because it is consistent with the characteristics of our data. Also, it accounts for heterogeneity and CD which are the two core panel data issues [19]. The AMG is performed in two stages:

$$
\text { AMG-Stage1: } \Delta \mathrm{y}_{i t}=\alpha_{\mathrm{i}}+\mathrm{b}_{\mathrm{i}} \Delta \mathrm{x}_{\mathrm{it}}+\mathrm{c}_{\mathrm{i}} \mathrm{f}_{\mathrm{t}}+\sum_{\mathrm{t}=2}^{\mathrm{T}} \mathrm{d}_{\mathrm{t}} \Delta \mathrm{D}_{\mathrm{t}}+\mathrm{e}_{\mathrm{it}}
$$




$$
\text { AMG-Stage2: } \widehat{\mathrm{b}}_{\mathrm{AMG}}=\mathrm{N}^{-1} \sum_{\mathrm{i}=1}^{\mathrm{N}} \widehat{\mathrm{b}}_{\mathrm{i}}
$$

$x_{i t}$ and $y_{i t}$ are the observables. $f_{t}$ represents the unobserved common factor. The country-specific estimates of coefficients, the AMG estimator, and the time dummies are, respectively $b_{t}, \widehat{b}_{\mathrm{AMG}}$, and $d_{t}$. In addition, the DK, CS-ARDL, and the PCSE approach are used to ascertain the robustness of the findings. The DK is robust amidst serial and spatial dependence, heteroscedasticity, and CD. It accommodates balanced and unbalanced panels, both large and small sample sizes, and missing values [10]. The PCSE shares almost the same properties with the DK approach. Besides, the CS-ARDL accommodates non-stationary data, and is capable of addressing $\mathrm{CD}$ and endogeneity issues [3].

\section{Causality}

One limitation of the AMG estimator is that it does not give information about causality. Since the direction of causality aids policy direction, the Dumitrescu and Hurlin [20] test is applied to check the direction of causality. The $\mathrm{DH}$ equation is given as:

$$
y_{i, t}=\varsigma_{i}+\sum_{i=1}^{p} \xi_{i}^{(p)} y_{i, t-n}+\sum_{i=1}^{p} \pi_{i}^{(p)} x_{i, t-n}+\mu_{i, t}
$$

The intercept and coefficient $\varsigma_{i}$ and $\pi_{i}=\left(\pi_{i}^{(1)}, \ldots \pi_{i}^{(p)}\right)$ are fixed. The autoregressive parameter and regression coefficient are, respectively $\xi_{i}^{(p)}$ and $\pi_{i}^{(p)}$ (Fig. 2).

\section{Data and model}

The study made use of annual data spanning 1990-2016 for N11 countries; a decision informed by data availability. The variables have been carefully selected with respect to economic theory, data availability, and empirical literature. Two core sustainability indicators (HDI and EF) have been used. The EF has been widely embraced as a comprehensive environmental indicator $[45,46,49,50$, 52]. The EF is superior to other metrics as it goes further to show how production, investment, and consumption inhabit the regenerative capacity of the Earth [55].

On the other hand, the HDI, designed by the UNDP, is a composite index that englobes three components (adult literacy, per capita gross national income, and life expectancy at birth). Today, the HDI is widely used as an indicator of human well-being $[40,65]$, though it has its limitation. See the concluding section of this study for the limitations of HDI as an indicator of human well-being. Unlike previous studies that

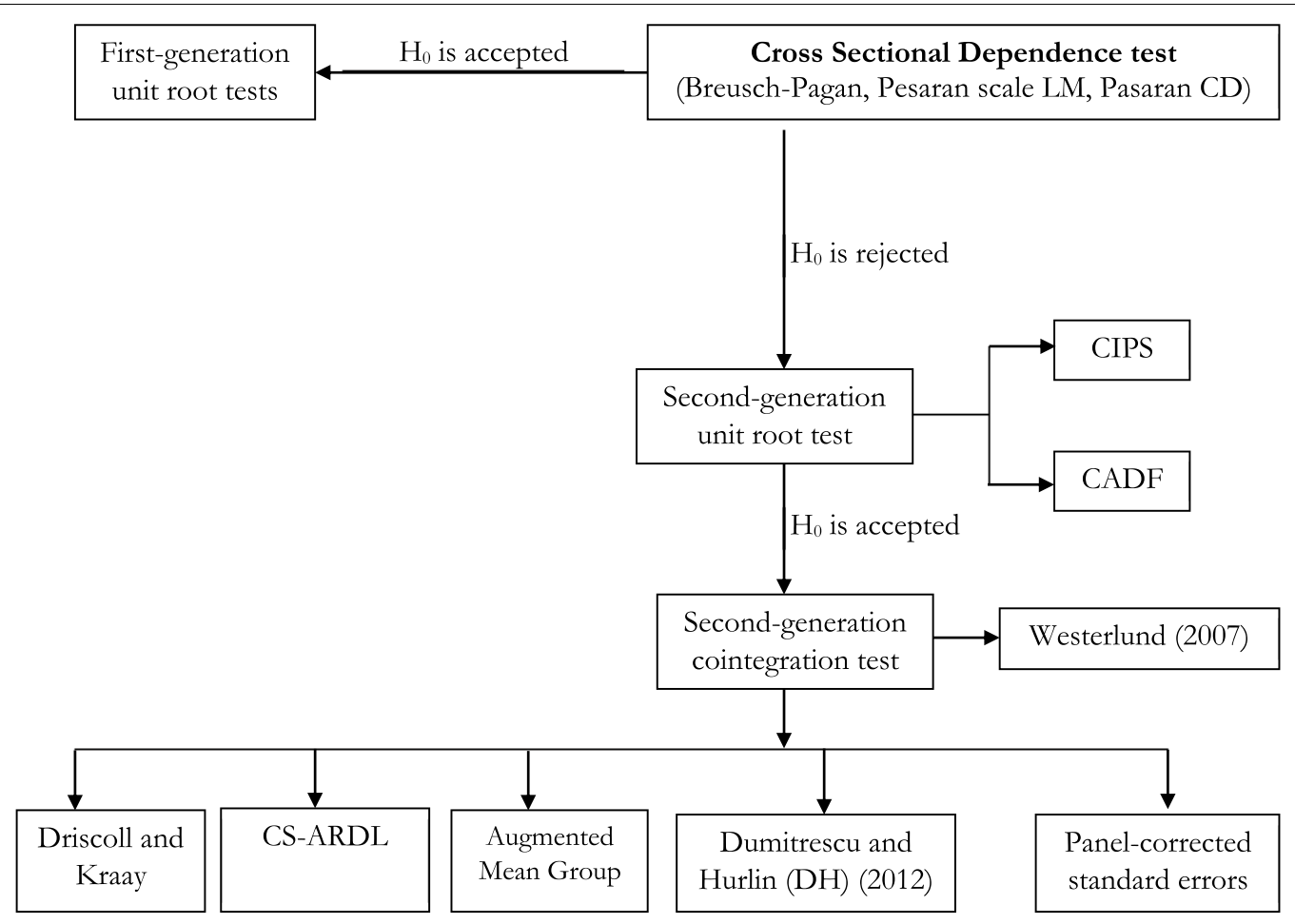

Note: The CS-ARDL was estimated to cushion the effects of endogeneity.

Fig. 2 Methodological schema of the study 
used the ratio of private credit to GDP, the ratio of current liabilities to GDP, and the ratio of deposits and loans to GDP to measure financial development, the current study used a broad-based financial development index recently introduced by the IMF. This index is way superior to those used by earlier studies in that, it considers the complex multidimensional nature of financial development. It summarizes how developed financial institutions and financial markets are, in terms of access, depth, and efficiency. See Sahay et al. [64] for more information on the index. However, recent studies like Iorember et al. [30] and Kassouri and Altıntaș [31] have used this index. The development of the financial system is associated with access to funds. When people have access to funding, they are more like to consume renewables, hence an improvement in environmental quality. Unsustainable natural resource consumption and exploration reduce the biocapacity, deplete forest, and cause the EF to rise [46]. Despite its contribution to knowledge, innovation, and economic development, urbanization spreads emissions, negatively impacts local food production [80], decreases soil fertility [8], and generates environmental degradation. Globalization opens up the economy and allows for the importation of products, and technologies that could improve human well-being or add to the already existing emissions level [70].

To investigate whether the win-win or trade-off hypothesis is evident in N11 countries, we need to estimate the effect of EF on HDI, and HDI on EF. This study further considered the role of globalization, financial development, urbanization, biocapacity, and natural resource as major determinants of sustainability. The consideration of these variables will give a clearer picture of the applicability of (SDGs 3) and (SDGs 15) simultaneously. The models for this study are: $\tau_{0}-\tau_{6}$ and $\xi_{0}-\xi_{6}$ are the parameters to be estimated in Model 1 and 2, respectively. $t$ and $i$ are the time dimension and country, respectively. $i=1,2, \ldots, 11$, and as $t=1,2, \ldots 27 . \mu_{i 1 t}$ and $\mu_{i 2 t}$ are the error terms in model 1 and 2, respectively. Two variables (natural resources rent and urbanization) were not logged because these variables are already in their growth rates. See Table 2 for the measurements, symbols, and sources of the variables.

\section{Results}

This section presents the trend of the variables, descriptive statistic and correlation, CD tests, unit root tests, cointegration, and the parameter estimation results.

\section{Trend of the variables}

In Fig. 3, South Korea and Iran are the two countries with the largest EF. However, the EF appears to be relatively constant only in Pakistan and the Philippines. Figure 4 reveals declining biocapacity in almost all the countries, especially in Mexico, Indonesia, Turkey, and Iran. In Fig. 5, all the countries have witnessed an increase in their HDI over the years; suggesting improvement in human well-being. Figures 6,7 , and 8 present a clearer picture of the trend of each of these variables in the individual N11 countries (see "Appendix"). Table 3 presents the summary statistic of the variables in relation to their mean, minimum value, standard deviation, and maximum value. From the results, globalization has the highest average followed by urbanization. These show how urbanized and globalized the N11 countries

$$
\operatorname{lnef}_{i t}=\tau_{0}+\tau_{1} \operatorname{lnhd}_{i t}+\tau_{2} \operatorname{lnfd}_{i t}+\tau_{3} \mathrm{ub}_{i t}+\tau_{4} \operatorname{lnbi}_{i t}+\tau_{5} \operatorname{lngb}_{i t}+\tau_{6} \mathrm{nr}_{i t}+\mu_{i 1 t}
$$

$$
\operatorname{lnhd}_{i t}=\xi_{0}+\xi_{1} \operatorname{lnef}_{i t}+\xi_{2} \operatorname{lnfd}_{i t}+\xi_{3} \mathrm{ub}_{i t}+\xi_{4} \operatorname{lnbi}_{i t}+\xi_{5} \operatorname{lngb}_{i t}+\xi_{5} \mathrm{nr}_{i t}+\mu_{i 2 t}
$$

Table 2 Description of variables

\begin{tabular}{lllll}
\hline S/N & Variables & Measurement & Source & Symbols \\
\hline 1 & Ecological Footprint & global hectares per capita & GFN (2019b) & ef \\
2 & Biocapacity & global hectares per capita & GFN [24] & bi \\
3 & Natural resource & Natural resources rent (\% of GDP) & WDI [81] & ub \\
4 & Urbanization & \% of total population & WDI [81] & go $[35]$ \\
5 & Globalization & Overall KOF index & IMF [29] & fd \\
6 & Financial development & Broad-based index of financial depth access & UNDP [76] & hd \\
\hline
\end{tabular}




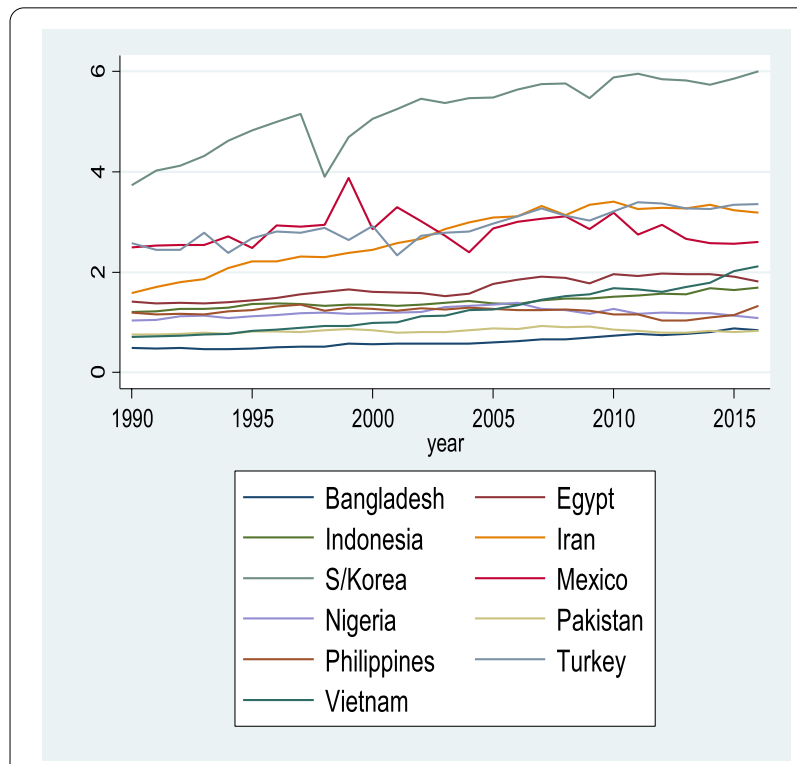

Fig. 3 EF in N11 countries

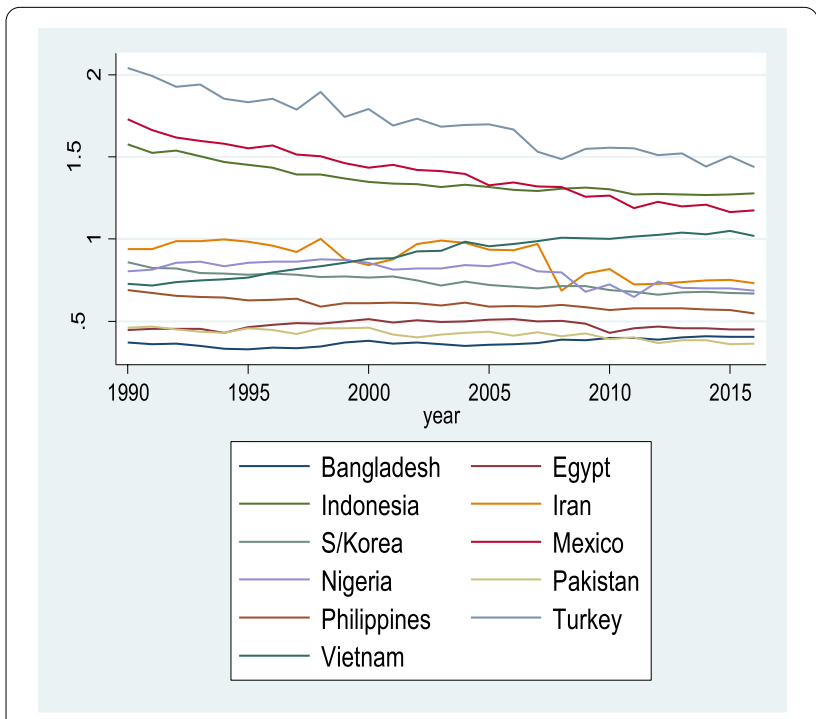

Fig. 4 Biocapacity in N11 countries

are. Urbanization is the most volatile of the variables while financial development is the least volatile of the variables.

All the variables, except natural resources, are positively associated with EF. Apart from EF, the remaining variables show a negative correlation with natural resources. HDI, globalization, and biocapacity are positively associated with financial development and urbanization.

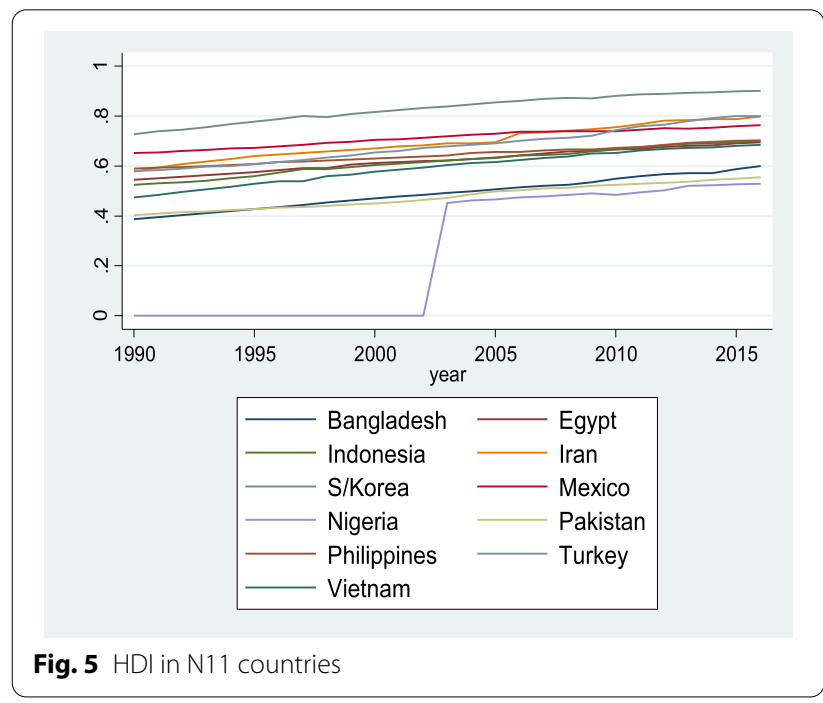

Table 4 confirms the presence of $\mathrm{CD}$. This finding is not strange, as all the N11 countries are signatories to various environmental sustainability treaties, like the Paris Agreement of 2015. Both unit root tests (see Table 5) affirmed non-stationarity of the variables at their level form. However, the stationarity of the variables was confirmed after their first difference. With these results, we can comfortably proceed with the cointegration test.

Table 6 confirms cointegration. $G_{t}$ and $P_{t}$, in both models show probability values that are significant which makes it difficult to reject the null hypothesis of no cointegration. Cointegration is a prerequisite for parameter estimation. Since this condition has been met, we now proceed with the AMG and other estimations.

The findings in Table 7, Model 1, reveal that natural resources and globalization reduce the EF. A one percent increase in natural resources rent reduce the EF by $0.023 \%, 0.239 \%$, and $0.412 \%$ in the AMG, PCSE, and DK estimators, respectively. The intuition here is that natural resources rent does not harm the environment in the $\mathrm{N} 11$ countries. Also, a one percent increase in globalization reduces the EF by $0.049 \%, 0.087 \%$, and $0.085 \%$ in the AMG, PCSE, and DK estimators, respectively. The negative relationship between globalization and EF as shown in the three estimators confirmed that globalization is consistent with environmental sustainability in the N11 countries. Conversely, urbanization, biocapacity, and financial development increase EF. A one percent increase in urbanization is associated with $0.14 \%$, $0.21 \%$, and $0.03 \%$ increase in EF in the AMG, PCSE, and DK estimators, respectively. The nexus between financial development and EF is positive and significant across the three estimators; suggesting that financial development increases the EF by $0.02 \%, 0.01 \%$, and $0.27 \%$ in the AMG, 
Table 3 Descriptive statistics results

\begin{tabular}{|c|c|c|c|c|c|c|c|}
\hline Statistics & InEF & NR & InFD & UB & $\ln B \mid$ & $\ln G B$ & InHD \\
\hline Mean & 1.982 & 6.679 & 0.332 & 47.72 & 0.878 & 54.81 & 0.602 \\
\hline SD & 1.319 & 7.887 & 0.159 & 16.64 & 0.428 & 11.36 & 0.171 \\
\hline Minimum & 0.458 & 0.001 & 0.000 & 19.81 & 0.329 & 27.71 & 0.002 \\
\hline Maximum & 6.000 & 34.95 & 0.858 & 79.57 & 2.038 & 79.19 & 0.901 \\
\hline \multicolumn{8}{|c|}{ Correlation results } \\
\hline $\ln E F$ & 1 & & & & & & \\
\hline$N R$ & -0.131 & 1 & & & & & \\
\hline InFD & 0.445 & -0.276 & 1 & & & & \\
\hline UB & 0.047 & -0.414 & 0.009 & 1 & & & \\
\hline $\ln B \mid$ & 0.324 & -0.014 & 0.164 & 0.569 & 1 & & \\
\hline $\operatorname{lnGB}$ & 0.577 & -0.284 & 0.002 & 0.518 & 0.230 & 1 & \\
\hline $\ln H D$ & 0.121 & -0.240 & 0.167 & 0.265 & 0.229 & 0.592 & 1 \\
\hline
\end{tabular}

Table 4 Cross-sectional dependence results

\begin{tabular}{lccc}
\hline Variables & Breusch-Pagan LM & Pesaran scaled LM & Pesaran CD \\
\hline EF (log) & $561.9135^{\mathrm{a}}$ & $48.3323^{\mathrm{a}}$ & $18.38443^{\mathrm{a}}$ \\
NR & $498.8934^{\mathrm{a}}$ & $69.5623^{\mathrm{a}}$ & $22.67538^{\mathrm{a}}$ \\
FD (log) & $420.9936^{\mathrm{a}}$ & $34.8962^{\mathrm{a}}$ & $17.89292^{\mathrm{a}}$ \\
UB & $1583.678^{\mathrm{a}}$ & $105.6483^{\mathrm{a}}$ & $24.74673^{\mathrm{a}}$ \\
BI (log) & $806.5597^{\mathrm{a}}$ & $71.44687^{\mathrm{a}}$ & $7.648187^{\mathrm{a}}$ \\
GB (log) & $1318.610^{\mathrm{a}}$ & $120.4805^{\mathrm{a}}$ & $36.29245^{\mathrm{a}}$ \\
HD (log) & $1400.348^{\mathrm{a}}$ & $128.2739^{\mathrm{a}}$ & $37.38887^{\mathrm{a}}$ \\
\hline
\end{tabular}

${ }^{a}$ Implies statistical significance at $1 \%$ level

Table 5 Unit root results

\begin{tabular}{llllll}
\hline Variables & \multicolumn{2}{l}{ Level } & & & \multicolumn{2}{l}{ First difference } \\
\cline { 2 - 3 } \cline { 6 - 7 } & CIPS & CADF & & CIPS & CADF \\
\hline EF (log) & -2.564 & 11.23 & & $-5.186^{\mathrm{a}}$ & $17.67^{\mathrm{b}}$ \\
NR & -1.876 & 13.56 & & $-4.654^{\mathrm{a}}$ & $22.43^{\mathrm{a}}$ \\
FD $(\log )$ & -1.342 & 12.67 & & $-3.287^{\mathrm{a}}$ & $16.34^{\mathrm{a}}$ \\
UB & -1.345 & 10.32 & & $-2.768^{\mathrm{a}}$ & $15.56^{\mathrm{b}}$ \\
BI (log) & -1.416 & 15.89 & & $-5.199^{\mathrm{a}}$ & $18.32^{\mathrm{a}}$ \\
GB (log) & -2.561 & 10.45 & & $-3.167^{\mathrm{b}}$ & $15.45^{\mathrm{b}}$ \\
HD (log) & -1.632 & 16.98 & & $-4.867^{\mathrm{a}}$ & $19.42^{\mathrm{b}}$ \\
\hline
\end{tabular}

a,b Imply statistical significance at the $1 \%$ and $5 \%$ levels, respectively

PCSE, and DK estimators, respectively. Also, biocapacity increases the EF by $0.15 \%, 0.34 \%$, and $0.43 \%$ in the AMG, PCSE, and DK estimators, respectively. The key variable in Model 2 is the EF which shows a positive relationship with human well-being. In the same model (Model 2), natural resources, financial development, globalization, and biocapacity exact a positive impact on human well-being and are consistent across all estimators. This
Table 6 Westerlund cointegration results

\begin{tabular}{lcrl}
\hline Statistic & Value & $\boldsymbol{Z}$ value & Robust $\boldsymbol{P}$ value \\
\hline Model 1 & & \\
$G_{t}$ & $-4.956^{\mathrm{a}}$ & -4.459 & 0.000 \\
$G_{a}$ & -1.878 & 2.576 & 0.431 \\
$P_{t}$ & $-12.98^{\mathrm{a}}$ & -7.437 & 0.000 \\
$P_{a}$ & -3.867 & 2.921 & 0.410 \\
Model 2 & & & \\
$G_{t}$ & $-3.945^{\mathrm{b}}$ & -2.887 & 0.021 \\
$G_{a}$ & -5.878 & 3.597 & 0.860 \\
$P_{t}$ & $-10.659^{\mathrm{c}}$ & -2.422 & 0.044 \\
$P_{a}$ & -3.861 & 1.874 & 0.712 \\
$\mathrm{a}, \mathrm{b}, \mathrm{c}$ Significance at $1 \%, 5 \%$ and $10 \%$ levels, respectively &
\end{tabular}

confirms that the aforementioned variables promote human well-being in N11 countries.

The country-wise AMG results are shown in Tables 8 and 9. In Table 8, natural resources abate environmental degradation in Vietnam, Pakistan, Mexico, Iran, Egypt, and the Philippines, but not in Bangladesh, S/ Korea, Nigeria, Indonesia, and Turkey. In Nigeria, for instance, crude oil exploration, the country's major natural resource, has caused so much environmental havoc, especially in the Niger Delta. The situation is not even better in Indonesia where coal consumption is increasing the country's footprint [37]. Financial development contributes to environmental quality in Nigeria, Mexico, and the Philippines. Urbanization and globalization have shown mixed results. The only consistent results in Table 8 relate to the effect of biocapacity on the EF. As earlier noted, all the N11 countries are harboring an ecological deficit territory as a result of their dwindling biocapacity. 
Table 7 AMG, PCSE, and Dristol/Kraay results

\begin{tabular}{|c|c|c|c|}
\hline Variables & AMG & PCSE (AR(1)) & Driscoll/Kraay \\
\hline \multicolumn{4}{|l|}{ Model 1} \\
\hline NR & $-0.023(-5.97)^{\mathrm{a}}$ & $-0.239(-4.13)^{\mathrm{a}}$ & $-0.412(-4.84)^{\mathrm{a}}$ \\
\hline FD (log) & $0.021(4.21)^{\mathrm{a}}$ & $0.013(5.65)^{\mathrm{a}}$ & $0.371(2.30)^{b}$ \\
\hline UB & $0.142(3.36)^{\mathrm{a}}$ & $0.210(3.32)^{\mathrm{a}}$ & $0.034(6.17)^{\mathrm{a}}$ \\
\hline GB (log) & $-0.049(-1.02)$ & $-0.087(-1.81)^{c}$ & $-0.085(-1.50)$ \\
\hline $\mathrm{BI}(\log )$ & $0.154(2.34)^{b}$ & $0.345(5.06)^{\mathrm{a}}$ & $0.434(4.06)^{\mathrm{a}}$ \\
\hline HD (log) & $0.056(2.67)^{b}$ & $1.176(4.08)^{\mathrm{a}}$ & $1.567(9.67)^{\mathrm{a}}$ \\
\hline _cons & $-3.23(-7.63)^{a}$ & $-0.267(1.32)$ & $-1.218(0.68)$ \\
\hline \multicolumn{4}{|l|}{ Model 2} \\
\hline NR & $0.234(1.34)$ & $0.871(1.27)$ & $0.671(6.67)^{\mathrm{a}}$ \\
\hline FD (log) & $0.218(4.78)^{\mathrm{a}}$ & $0.310(3.34)^{\mathrm{a}}$ & $0.982(6.34)^{\mathrm{a}}$ \\
\hline UB & $-0.453(5.06)^{\mathrm{a}}$ & $-0.342(4.09)^{\mathrm{a}}$ & $-0.564(1.24)$ \\
\hline GB (log) & $0.054(6.18)^{\mathrm{a}}$ & $0.102(4.45)^{\mathrm{a}}$ & $0.005(4.51)^{\mathrm{a}}$ \\
\hline BI $(\log )$ & $-0.034(-1.04)$ & $-0.546(-5.19)^{\mathrm{a}}$ & $-0.654(-2.63)^{b}$ \\
\hline $\mathrm{EF}(\log )$ & $0.329(2.49)^{b}$ & $0.338(6.96)^{\mathrm{a}}$ & $0.432(7.32)^{\mathrm{a}}$ \\
\hline _cons & $0.678(4.86)^{\mathrm{a}}$ & $-1.463(-8.27)^{\mathrm{a}}$ & $-1.215(-6.69)^{\mathrm{a}}$ \\
\hline Number of regressors & 6 & 6 & 6 \\
\hline Number of observations & 280 & 280 & 280 \\
\hline Number of groups & 11 & 11 & 11 \\
\hline$R$-squared (model 1) & - & 0.8896 & 0.8711 \\
\hline$R$-squared (model 2) & - & 0.9302 & 0.8742 \\
\hline Wald chi $^{2}$ (model 1) & 31.21 & - & - \\
\hline Wald chi $^{2}$ (model 2) & 42.15 & - & - \\
\hline
\end{tabular}

$\overline{\mathrm{a}, \mathrm{b}, \mathrm{c}}$ Significance at $1 \%, 5 \%$, and $10 \%$ levels, respectively. () are the $t$-stat

Table 8 Model 1 with InEF as the dependent variable

\begin{tabular}{|c|c|c|c|c|c|c|c|c|c|c|}
\hline & $\begin{array}{l}\text { Bangladesh } \\
\text { InEF }\end{array}$ & $\begin{array}{l}\text { Egypt } \\
\text { InEF }\end{array}$ & $\begin{array}{l}\text { Indonesia } \\
\text { InEF }\end{array}$ & $\begin{array}{l}\text { Iran } \\
\text { InEF }\end{array}$ & $\begin{array}{l}\text { S/Korea } \\
\text { InEF }\end{array}$ & $\begin{array}{l}\text { Mexico } \\
\text { InEF }\end{array}$ & $\begin{array}{l}\text { Nigeria } \\
\text { InEF }\end{array}$ & $\begin{array}{l}\text { Pakistan } \\
\text { InEF }\end{array}$ & $\begin{array}{l}\text { Philippines } \\
\text { InEF }\end{array}$ & $\begin{array}{l}\text { Turkey } \\
\text { InEF }\end{array}$ \\
\hline$N R$ & $\begin{array}{l}0.04 \\
(1.38)\end{array}$ & $\begin{array}{l}-0.01 \\
(-0.14)\end{array}$ & $\begin{array}{l}0.12^{\mathrm{a}} \\
(6.16)\end{array}$ & $\begin{array}{l}-0.00 \\
(-0.10)\end{array}$ & $\begin{array}{l}0.02 \\
(1.07)\end{array}$ & $\begin{array}{l}-0.08^{\mathrm{a}} \\
(-7.91)\end{array}$ & $\begin{array}{l}0.02^{\mathrm{a}} \\
(2.82)\end{array}$ & $\begin{array}{l}-0.08^{\mathrm{a}} \\
(-5.45)\end{array}$ & $\begin{array}{l}-0.07^{b} \\
(-2.28)\end{array}$ & $\begin{array}{l}0.02 \\
(0.64)\end{array}$ \\
\hline $\operatorname{InFD}$ & $\begin{array}{l}0.02 \\
(0.32)\end{array}$ & $\begin{array}{l}0.04^{\mathrm{a}} \\
(8.51)\end{array}$ & $\begin{array}{l}0.04^{\mathrm{a}} \\
(4.60)\end{array}$ & $\begin{array}{l}0.11 \\
(0.82)\end{array}$ & $\begin{array}{l}0.74^{\mathrm{a}} \\
(4.44)\end{array}$ & $\begin{array}{l}-0.22^{b} \\
(-2.38)\end{array}$ & $\begin{array}{l}-0.33^{\mathrm{a}} \\
(-14.1)\end{array}$ & $\begin{array}{l}0.06^{\mathrm{a}} \\
(3.24)\end{array}$ & $\begin{array}{l}-0.04 \\
(-0.46)\end{array}$ & $\begin{array}{l}0.06^{\mathrm{a}} \\
(5.60)\end{array}$ \\
\hline UB & $\begin{array}{l}2.37^{a} \\
(2.88)\end{array}$ & $\begin{array}{l}-0.18 \\
(-0.06)\end{array}$ & $\begin{array}{l}-0.61 \\
(-0.84)\end{array}$ & $\begin{array}{l}5.64^{\mathrm{a}} \\
(4.83)\end{array}$ & $\begin{array}{l}26.9^{a} \\
(4.43)\end{array}$ & $\begin{array}{l}9.93^{\mathrm{a}} \\
(4.24)\end{array}$ & $\begin{array}{l}5.90^{\mathrm{b}} \\
(2.58)\end{array}$ & $\begin{array}{l}-2.48 \\
(-0.84)\end{array}$ & $\begin{array}{l}1.13 \\
(0.46)\end{array}$ & $\begin{array}{l}-4.81 \\
(-0.61)\end{array}$ \\
\hline $\ln G B$ & $\begin{array}{l}-0.59^{b} \\
(-2.31)\end{array}$ & $\begin{array}{l}0.08^{\mathrm{a}} \\
(7.15)\end{array}$ & $\begin{array}{l}0.34^{b} \\
(2.43)\end{array}$ & $\begin{array}{l}-0.02 \\
(-0.14)\end{array}$ & $\begin{array}{l}-1.48^{\mathrm{a}} \\
(-4.06)\end{array}$ & $\begin{array}{l}-0.50 \\
(-0.35)\end{array}$ & $\begin{array}{l}-0.41^{c} \\
(-1.83)\end{array}$ & $\begin{array}{l}0.13 \\
(0.50)\end{array}$ & $\begin{array}{l}0.09^{a} \\
(6.89)\end{array}$ & $\begin{array}{l}-0.44^{\mathrm{a}} \\
(-6.12)\end{array}$ \\
\hline$\underline{\ln B \mid}$ & $\begin{array}{l}0.66^{\mathrm{b}} \\
(2.38)\end{array}$ & $\begin{array}{l}0.10^{\mathrm{a}} \\
(3.70)\end{array}$ & $\begin{array}{l}0.30^{\mathrm{a}} \\
(9.18)\end{array}$ & $\begin{array}{l}0.33^{\mathrm{a}} \\
(3.53)\end{array}$ & $\begin{array}{l}0.54 \\
(1.22)\end{array}$ & $\begin{array}{l}0.24^{\mathrm{a}} \\
(8.30)\end{array}$ & $\begin{array}{l}0.37^{\mathrm{a}} \\
(8.39)\end{array}$ & $\begin{array}{l}0.57^{\mathrm{a}} \\
(5.43)\end{array}$ & $\begin{array}{l}0.52 \\
(0.75)\end{array}$ & $\begin{array}{l}0.94^{c} \\
(1.80)\end{array}$ \\
\hline $\ln H D$ & $\begin{array}{l}1.39 \\
(1.11)\end{array}$ & $\begin{array}{l}-0.99 \\
(-0.39)\end{array}$ & $\begin{array}{l}0.17 \\
(0.13)\end{array}$ & $\begin{array}{l}0.77 \\
(1.25)\end{array}$ & $\begin{array}{l}8.31^{\mathrm{a}} \\
(5.20)\end{array}$ & $\begin{array}{l}3.15^{\mathrm{a}} \\
(19.2)\end{array}$ & $\begin{array}{l}2.22^{\mathrm{a}} \\
(9.05)\end{array}$ & $\begin{array}{l}0.49 \\
(0.79)\end{array}$ & $\begin{array}{l}2.24 \\
(0.67)\end{array}$ & $\begin{array}{l}0.36 \\
(0.17)\end{array}$ \\
\hline _cons & $\begin{array}{l}-3.81^{b} \\
(-2.19)\end{array}$ & $\begin{array}{l}0.11 \\
(0.01)\end{array}$ & $\begin{array}{l}1.30 \\
(0.48)\end{array}$ & $\begin{array}{l}-21.5^{\mathrm{a}} \\
(-4.85)\end{array}$ & $\begin{array}{l}-99.2^{\mathrm{a}} \\
(-4.10)\end{array}$ & $\begin{array}{l}-38.0 \\
(-0.42)\end{array}$ & $\begin{array}{l}-16.2^{b} \\
(-2.32)\end{array}$ & $\begin{array}{l}8.78 \\
(0.97)\end{array}$ & $\begin{array}{l}-3.59 \\
(-0.32)\end{array}$ & $\begin{array}{l}21.6 \\
0.68\end{array}$ \\
\hline
\end{tabular}

Source: $t$ statistics in parentheses; $={ }^{\prime \prime c} p<0.10,{ }^{b} p<0.05,{ }^{a} p<0.001 "$

Further findings in Table 8 reveals that human wellbeing increases the EF in all the countries except in Egypt. This further emphasized the trade-off between both variables. EF is the key variable of concern in Table 9. From the results obtained, EF exacts a negative and insignificant impact on human well-being only in 
Table 9 Model 2 with InHD as the dependent variable

\begin{tabular}{|c|c|c|c|c|c|c|c|c|c|c|c|}
\hline & $\begin{array}{l}\text { Bangladesh } \\
\text { InHD }\end{array}$ & $\begin{array}{l}\text { Egypt } \\
\text { InHD }\end{array}$ & $\begin{array}{l}\text { Indonesia } \\
\text { InHD }\end{array}$ & $\begin{array}{l}\text { Iran } \\
\text { InHD }\end{array}$ & $\begin{array}{l}\text { S/Korea } \\
\text { InHD }\end{array}$ & $\begin{array}{l}\text { Mexico } \\
\text { InHD }\end{array}$ & $\begin{array}{l}\text { Nigeria } \\
\text { InHD }\end{array}$ & $\begin{array}{l}\text { Pakistan } \\
\text { InHD }\end{array}$ & $\begin{array}{l}\text { Philippines } \\
\text { InHD }\end{array}$ & $\begin{array}{l}\text { Turkey } \\
\text { InHD }\end{array}$ & $\begin{array}{l}\text { Vietnam } \\
\text { InHD }\end{array}$ \\
\hline NR & $\begin{array}{l}-0.00 \\
(-1.40)\end{array}$ & $\begin{array}{l}0.00^{c} \\
(1.91)\end{array}$ & $\begin{array}{l}-0.00^{\mathrm{a}} \\
(-2.60)\end{array}$ & $\begin{array}{l}-0.00 \\
(-0.03)\end{array}$ & $\begin{array}{l}-0.00^{\mathrm{a}} \\
(-5.03)\end{array}$ & $\begin{array}{l}-0.00 \\
(-0.51)\end{array}$ & $\begin{array}{l}0.00 \\
(0.10)\end{array}$ & $\begin{array}{l}-0.00 \\
(-1.20)\end{array}$ & $\begin{array}{l}-0.00 \\
(-0.51)\end{array}$ & $\begin{array}{l}0.00 \\
(1.42)\end{array}$ & $\begin{array}{l}0.00 \\
(0.56)\end{array}$ \\
\hline $\ln F D$ & $\begin{array}{l}0.00 \\
(0.27)\end{array}$ & $\begin{array}{l}0.01^{\mathrm{a}} \\
(3.21)\end{array}$ & $\begin{array}{l}0.02^{b} \\
(2.58)\end{array}$ & $\begin{array}{l}-0.13^{a} \\
(-3.27)\end{array}$ & $\begin{array}{l}0.05^{\mathrm{a}} \\
(5.07)\end{array}$ & $\begin{array}{l}-0.01^{c} \\
(-1.91)\end{array}$ & $\begin{array}{l}0.09^{c} \\
(1.79)\end{array}$ & $\begin{array}{l}0.00 \\
(0.60)\end{array}$ & $\begin{array}{l}0.00 \\
(0.46)\end{array}$ & $\begin{array}{l}-0.01 \\
(-0.95)\end{array}$ & $\begin{array}{l}0.07^{b} \\
(1.99)\end{array}$ \\
\hline UB & $\begin{array}{l}-0.28^{b} \\
(-2.04)\end{array}$ & $\begin{array}{l}0.02 \\
(0.10)\end{array}$ & $\begin{array}{l}0.09 \\
(1.00)\end{array}$ & $\begin{array}{l}-1.83^{\mathrm{a}} \\
(-2.86)\end{array}$ & $\begin{array}{l}-1.02^{\mathrm{a}} \\
(-3.64)\end{array}$ & $\begin{array}{l}-0.73 \\
(-0.65)\end{array}$ & $\begin{array}{l}-3.31^{\mathrm{a}} \\
(-4.64)\end{array}$ & $\begin{array}{l}-4.12^{\mathrm{a}} \\
(-5.34)\end{array}$ & $\begin{array}{l}0.60^{\mathrm{a}} \\
(4.75)\end{array}$ & $\begin{array}{l}-3.49^{a} \\
(-3.93)\end{array}$ & $\begin{array}{l}-1.27^{c} \\
(-1.93)\end{array}$ \\
\hline $\ln G B$ & $\begin{array}{l}0.02^{\mathrm{a}} \\
(3.56)\end{array}$ & $\begin{array}{l}0.01^{\mathrm{a}} \\
(5.39)\end{array}$ & $\begin{array}{l}0.00 \\
(0.12)\end{array}$ & $\begin{array}{l}-0.02 \\
(-0.42)\end{array}$ & $\begin{array}{l}0.09^{b} \\
(5.54)\end{array}$ & $\begin{array}{l}0.08^{\mathrm{b}} \\
(2.09)\end{array}$ & $\begin{array}{l}-0.02 \\
(-0.07)\end{array}$ & $\begin{array}{l}0.20^{\mathrm{b}} \\
(2.13)\end{array}$ & $\begin{array}{l}0.03^{\mathrm{a}} \\
(7.45)\end{array}$ & $\begin{array}{l}0.00^{\mathrm{b}} \\
(2.07)\end{array}$ & $\begin{array}{l}0.03^{\mathrm{a}} \\
(6.85)\end{array}$ \\
\hline$\underline{\ln B \mid}$ & $\begin{array}{l}-0.04 \\
(-0.68)\end{array}$ & $\begin{array}{l}-0.01 \\
(-0.80)\end{array}$ & $\begin{array}{l}-0.13^{\mathrm{a}} \\
(-7.43)\end{array}$ & $\begin{array}{l}-0.06^{b} \\
(-2.04)\end{array}$ & $\begin{array}{l}-0.04^{c} \\
(-1.90)\end{array}$ & $\begin{array}{l}0.06^{\mathrm{a}} \\
(7.99)\end{array}$ & $\begin{array}{l}-0.11^{\mathrm{a}} \\
(-3.22)\end{array}$ & $\begin{array}{l}-0.00^{\mathrm{a}} \\
(-9.87)\end{array}$ & $\begin{array}{l}0.01^{\mathrm{a}} \\
(4.67)\end{array}$ & $\begin{array}{l}-0.10^{\mathrm{a}} \\
(-4.81)\end{array}$ & $\begin{array}{l}-0.14^{\mathrm{a}} \\
-(8.43)\end{array}$ \\
\hline $\ln E F$ & $\begin{array}{l}0.05 \\
(1.13)\end{array}$ & $\begin{array}{l}-0.00 \\
(-0.01)\end{array}$ & $\begin{array}{l}0.00 \\
(0.08)\end{array}$ & $\begin{array}{l}0.15^{b} \\
(2.30)\end{array}$ & $\begin{array}{l}0.04^{\mathrm{a}} \\
(5.71)\end{array}$ & $\begin{array}{l}0.00 \\
(0.60)\end{array}$ & $\begin{array}{l}0.21 \\
(0.95)\end{array}$ & $\begin{array}{l}0.08 \\
(1.19)\end{array}$ & $\begin{array}{l}0.03^{b} \\
(2.01)\end{array}$ & $\begin{array}{l}0.00^{\mathrm{a}} \\
(8.76)\end{array}$ & $\begin{array}{l}0.34^{\mathrm{a}} \\
(7.45)\end{array}$ \\
\hline _cons & $\begin{array}{l}-0.15 \\
(-0.42)\end{array}$ & $\begin{array}{l}-0.73 \\
(-0.67)\end{array}$ & $\begin{array}{l}-0.88^{\mathrm{a}} \\
(-2.64)\end{array}$ & $\begin{array}{l}6.71^{\mathrm{a}} \\
(2.68)\end{array}$ & $\begin{array}{l}3.34^{\mathrm{a}} \\
(2.82)\end{array}$ & $\begin{array}{l}2.32 \\
(0.51)\end{array}$ & $\begin{array}{l}10.3 \\
(0.67)\end{array}$ & $\begin{array}{l}12.4^{\mathrm{a}} \\
(5.09)\end{array}$ & $\begin{array}{l}-2.74^{\mathrm{a}} \\
(-4.88)\end{array}$ & $\begin{array}{l}13.5^{\mathrm{a}} \\
(3.77)\end{array}$ & $\begin{array}{l}0.19^{a} \\
(4.19)\end{array}$ \\
\hline
\end{tabular}

$t$ statistics in parentheses; $=" \mathrm{pc} p<0.10,{ }^{\mathrm{b}} p<0.05,{ }^{\mathrm{a}} p<0.001 "$

Egypt. The positive impact of EF on human well-being in the remaining countries infers trade-offs. Meaning that the attainment of human well-being objectives is achieved at the expense of environmental degradation in these countries.

\section{Discussion}

The negative relationship between natural resources rent and EF suggests that the exploration of natural resource ensures environmental sustainability. The finding corroborates the results of Danish et al. [18] for BRICS, Zhang et al. [88] for Pakistan, Erdoğan et al. [22] for subSaharan Africa, Zafar et al. [85] for the USA, Kongbuamai et al. [36] for ASEAN countries, and Pata et al. [58] for countries with the largest EF. However, it contradicts the findings of Nathaniel [46] and Wang et al. [78] who reported the adverse effect of natural resources rent on the EF in ASEAN and G7 countries, respectively. The discrepancies in the findings could have been informed by the choice of variables and estimation techniques. For instance, Nathaniel [46] controlled for human capital and economic growth, while the current study did not consider both variables.

The findings revealed that globalization has no adverse effects on the environment. Globalization may not be harmful especially when it is properly managed through the enactment of strict regulation to curtail the importation of harmful products and "dirty" technology. This finding is in line with those of Saud et al. [66] for OBOR, Ahmed et al. [5] for Japan, Pata [58] for the USA, and Pandey et al. [57] for Asia, but contradicts the findings of Ahmed et al. [6] for the USA, Yang et al. [82, 83] for Gulf
Cooperation Council countries, Pata and Caglar [59] for China, and Kirikkaleli et al. [34] for Turkey. Urbanization increases economic activities which drive energy consumption. Since the energy source in N11 countries is mainly non-renewable (e.g., fossil fuels) it is possible for an increase in energy demand to create ecological pressure, hence increasing the EF. The increased urbanization rate in N11 countries could be attributed to economic expansion which results in low energy efficiency, waste generation, and increased energy demand. Urbanization accelerates human demand on the Earth's resources which reduce the biocapacity and increase the EF [56]. The findings in this study complement those of Ahmed et al. [4], Erdoğan et al. [22], Hassan et al. [27], Nathaniel et al. [48, 52, 53], Ulucak and Bilgili [74]. On the flip side, Danish et al. [18] and Nathaniel et al. [50] discovered no harmful impact of urbanization on EF in BRICS.

The positive impact of financial development on the EF confirms the lingering argument that financial development promotes economic growth which triggers human demand on ecological resources; hence an increase in the EF. This is in line with the findings of Usman et al. [77], Ahmed et al. [5], Yang et al. [83], Khalid et al. [32], Yang et al. [82], Sharma et al. [69], Yasin et al. [84], Saud et al. [66], Baloch et al. [10].

Interestingly, human well-being adds to the EF across the three specifications (AMG, DK, and PCSE). The intuition here is that the efforts/policies that are channeled toward promoting human well-being are not in consonance with environmental wellness, meaning that policies directed toward human well-being are causing environmental degradation. Simply put, a trade-off 
Table 10 CS-ARDL results

\begin{tabular}{lll}
\hline Variables & Model 1 & Model 2 \\
\hline Long-run results & & \\
NR & $-0.56(-4.52)^{\mathrm{a}}$ & $0.23(3.81)^{\mathrm{a}}$ \\
FD $(\log )$ & $0.04(5.67)^{\mathrm{a}}$ & $0.45(8.54)^{\mathrm{a}}$ \\
UB & $0.78(3.24)^{\mathrm{a}}$ & $-0.08(-6.87)^{\mathrm{a}}$ \\
GB $(\log )$ & $-0.01(-2.02)^{\mathrm{b}}$ & $0.76(5.34)^{\mathrm{a}}$ \\
BI $(\log )$ & $0.34(4.76)^{\mathrm{a}}$ & $-0.37(-2.12)^{\mathrm{b}}$ \\
HD $(\log )$ & $1.06(3.05)^{\mathrm{a}}$ & - \\
EF $(\log )$ & - & $0.16(5.25)^{\mathrm{a}}$ \\
Short-run results & & \\
NR & $0.18(3.67)^{\mathrm{a}}$ & $-0.65(3.24)^{\mathrm{a}}$ \\
FD (log) & $0.06(1.43)$ & $0.21(1.03)$ \\
UB & $1.23(1.18)$ & $-0.39(-2.22)^{\mathrm{b}}$ \\
GB (log) & $-0.25(-2.24)^{\mathrm{b}}$ & $0.04(3.39)^{\mathrm{a}}$ \\
BI (log) & $1.67(3.87)^{\mathrm{a}}$ & $-0.34(-1.57)$ \\
HD (log) & $0.13(7.23)^{\mathrm{a}}$ & - \\
EF (log) & - & $-1.52(-7.25)^{\mathrm{a}}$ \\
ECT $(-1)$ & $-0.73(-4.56)^{\mathrm{a}}$ & $-0.84(-6.73)^{\mathrm{a}}$ \\
\hline
\end{tabular}

a,b Significance at $1 \%$ and $5 \%$ levels, respectively. () are the $t$-stat

exists between EF and human well-being. Environmental quality and human well-being are two different sides of the same coin but have been considered in isolation in the N11 countries. The consideration of environmental objectives in policies designed to improve human well-being will aid the attainment of sustainability and inhibit environmental degradation. These findings are complemented in the CS-ARDL long-run results in Table 10. Besides, the short-run results in Table 10 affirmed the deteriorating impact of all the variables, except globalization, on the EF in the N11 countries.

In Model 2, EF increases human well-being. This outcome is appealing. It suggests that environmental sustainability policies amount to a welfare loss. That is, efforts to promote environmental sustainability declines human well-being. Environmental preservation policies are not compatible with human well-being in N11 countries. Natural resources have been a major source of foreign exchange earnings in the N11 countries, especially in Nigeria, Mexico, Iran, Egypt, and Indonesia. Natural resources can have an effect on human well-being directly or indirectly [38]. These resources yield income which could improve the wellbeing of the citizenry. However, the N11 countries still need to inculcate sustainable natural resource exploration practices so resources can regenerate to curb biocapacity depletion. Financial development leaves people with income that they can use to sustain their existence. Depending on the initial level of income, financial development could contribute to human wellbeing [33]. More so, financial development enhances technological innovation and human capital development by pooling out idle funds which are invested in socially beneficial areas [62]. Globalization opens up the economy and allows for the importation of technology and products which could improve human wellbeing [70].

MEA (2005) noted that the efforts made in relation to ecosystem improvement have actually improved human well-being but at a cost to the environment. The MEA further highlighted that the link between human wellbeing and the functioning of the ecosystem is a complex one that rests solely on human actions which could be positive or negative. The findings of this study have shown that (SDGs 15) and (SDGs 3) cannot be simultaneously achieved in the N11 countries. As noted by Bowen et al. (2017), it is vital for some SDGs to be prioritized in some regions of the world. Whether environmental quality should be sacrificed for well-being or economic growth has remained an unending debate in the literature. To ease the pathways to SDGs attainment, policymakers in the N11 countries must identify and deal with trade-offs that could frustrate the effective achievement of the SDGs by 2030 [71].

Table 11 presents different directions of causality. A feedback causality exists between globalization, financial development, human well-being, and EF. This suggests a strong link between the aforementioned variables and $E F$, especially between human well-being and EF which could inform necessary policy directions. A unidirectional causality flows from urbanization and biocapacity to EF, and from human well-being to biocapacity, urbanization, financial development, and globalization. However, no direction of causality exists between natural resources and EF, biocapacity and natural resources, globalization and natural resources, and between human well-being and natural resources.

\section{Conclusions}

This study examined the nexus between human wellbeing and EF in the N11 countries from 1990 to 2016. We started by checking for $\mathrm{CD}$ in the dataset. The existence of $\mathrm{CD}$ informed the use of econometric techniques (including unit root, cointegration, parameter estimation, and causality test) that are consistent with the nature of data. The findings revealed a trade-off between EF and human well-being. Natural resources and globalization decline the EF, while financial development and biocapacity add to the EF. The outcome of this study necessitated relevant policy directions. 
Table 11 D-H causality test

\begin{tabular}{|c|c|c|c|c|}
\hline Null hypothesis & $W$-stat & Zbar-stat & Probability & Decision \\
\hline $\mathrm{NR} \rightarrow \ln \mathrm{EF}$ & 1.589 & -0.845 & 0.397 & No causality \\
\hline $\operatorname{lnEF} \rightarrow \mathrm{NR}$ & 2.982 & 1.009 & 0.312 & \\
\hline $\ln F D \rightarrow \ln E F$ & 4.850 & 3.496 & 0.000 & $\begin{array}{l}\text { Bidirectional } \\
\text { causality }\end{array}$ \\
\hline $\ln E F \rightarrow \ln F D$ & 4.351 & 2.831 & 0.004 & \\
\hline $\ln G B \rightarrow \ln E F$ & 4.143 & 2.564 & 0.010 & $\begin{array}{c}\text { Bidirectional } \\
\text { causality }\end{array}$ \\
\hline $\ln E F \rightarrow \ln G B$ & 4.047 & 2.437 & 0.014 & \\
\hline $\mathrm{UB} \rightarrow \ln E F$ & 4.582 & 3.151 & 0.001 & $\begin{array}{l}\text { Unidirectional } \\
\text { causality }\end{array}$ \\
\hline $\ln E F \rightarrow \cup B$ & 2.599 & 0.503 & 0.614 & \\
\hline $\ln B \mid \rightarrow \ln E F$ & 3.283 & 1.416 & 0.156 & $\begin{array}{l}\text { Unidirectional } \\
\text { causality }\end{array}$ \\
\hline $\ln E F \rightarrow \operatorname{lnBl}$ & 4.328 & 2.811 & 0.004 & \\
\hline $\operatorname{InHD} \rightarrow \operatorname{InEF}$ & 3.775 & 1.846 & 0.064 & $\begin{array}{c}\text { Bidirectional } \\
\text { causality }\end{array}$ \\
\hline $\ln E F \rightarrow \ln E F$ & 6.753 & 3.264 & 0.001 & \\
\hline $\operatorname{lnFD} \rightarrow \mathrm{NR}$ & 4.208 & 2.632 & 0.008 & $\begin{array}{l}\text { Unidirectional } \\
\text { causality }\end{array}$ \\
\hline $\mathrm{NR} \rightarrow \ln F \mathrm{D}$ & 1.760 & -0.619 & 0.535 & \\
\hline $\operatorname{lnGB} \rightarrow \mathrm{NR}$ & 2.673 & 0.597 & 0.549 & No causality \\
\hline $\mathrm{NR} \rightarrow \ln \mathrm{GB}$ & 1.346 & -1.169 & 0.242 & \\
\hline $\mathrm{UB} \rightarrow \mathrm{NR}$ & 4.754 & 3.368 & 0.000 & $\begin{array}{c}\text { Bidirectional } \\
\text { causality }\end{array}$ \\
\hline $\mathrm{NR} \rightarrow \mathrm{UB}$ & 4.366 & 2.852 & 0.004 & \\
\hline $\ln \mathrm{Bl} \rightarrow \mathrm{NR}$ & 2.817 & 0.789 & 0.430 & No causality \\
\hline $\mathrm{NR} \rightarrow \ln \mathrm{Bl}$ & 2.717 & 0.656 & 0.511 & \\
\hline $\mathrm{InHD} \rightarrow \mathrm{NR}$ & 2.925 & 0.795 & 0.426 & No causality \\
\hline $\mathrm{NR} \rightarrow \mathrm{InHD}$ & 1.918 & -0.440 & 0.659 & \\
\hline $\ln G B \rightarrow \ln F D$ & 5.970 & 4.987 & 0.006 & $\begin{array}{l}\text { Unidirectional } \\
\text { causality }\end{array}$ \\
\hline $\ln F D \rightarrow \operatorname{lnGB}$ & 2.629 & 0.590 & 0.590 & \\
\hline $\mathrm{UB} \rightarrow \ln F D$ & 6.711 & 5.975 & 0.002 & $\begin{array}{c}\text { Bidirectional } \\
\text { causality }\end{array}$ \\
\hline $\operatorname{lnFD} \rightarrow \cup \mathrm{UB}$ & 5.198 & 3.959 & 0.008 & \\
\hline $\ln B \mid \rightarrow \ln F D$ & 3.382 & 1.541 & 0.123 & $\begin{array}{l}\text { Unidirectional } \\
\text { causality }\end{array}$ \\
\hline $\ln F D \rightarrow \ln B \mid$ & 5.711 & 4.643 & 0.061 & \\
\hline $\ln H D \rightarrow \operatorname{lnFD}$ & 4.716 & 2.993 & 0.002 & $\begin{array}{l}\text { Unidirectional } \\
\text { causality }\end{array}$ \\
\hline $\operatorname{lnFD} \rightarrow \ln H D$ & 1.948 & -0.403 & 0.686 & \\
\hline $\ln B \mid \rightarrow \ln G B$ & 4.444 & 2.965 & 0.003 & $\begin{array}{c}\text { Bidirectional } \\
\text { causality }\end{array}$ \\
\hline $\operatorname{lnGB} \rightarrow \ln B \mid$ & 3.903 & 2.244 & 0.024 & \\
\hline $\ln H D \rightarrow \ln G B$ & 4.815 & 3.124 & 0.001 & $\begin{array}{l}\text { Unidirectional } \\
\text { causality }\end{array}$ \\
\hline $\operatorname{lnGB} \rightarrow \ln H D$ & 2.042 & -0.285 & 0.775 & \\
\hline $\ln \mathrm{BI} \rightarrow \mathrm{UB}$ & 2.423 & 0.268 & 0.788 & $\begin{array}{l}\text { Unidirectional } \\
\text { causality }\end{array}$ \\
\hline $\mathrm{UB} \rightarrow \ln \mathrm{BI}$ & 4.959 & 3.654 & 0.000 & \\
\hline $\operatorname{InHD} \rightarrow \cup \mathrm{UB}$ & 5.380 & 3.819 & 0.000 & $\begin{array}{l}\text { Unidirectional } \\
\text { causality }\end{array}$ \\
\hline $\mathrm{UB} \rightarrow \mathrm{InHD}$ & 3.249 & 1.198 & 0.230 & \\
\hline $\ln H D \rightarrow \operatorname{lnBl}$ & 5.173 & 3.565 & 0.000 & $\begin{array}{l}\text { Unidirectional } \\
\text { causality }\end{array}$ \\
\hline $\operatorname{lnBl} \rightarrow \operatorname{lnHD}$ & 2.604 & 0.404 & 0.685 & \\
\hline
\end{tabular}

$\rightarrow$ represents "does not homogeneously cause"
Since there is a trade-off between EF and human wellbeing, it is recommended that policymakers come up with policy proposals that integrate the promotion of human well-being and environmental preservation. A strong and viable institutional framework can help mitigate the tradeoff and uphold the simultaneous attainment of human well-being and environmental sustainability goals. From our findings, globalization can ensure environmental sustainability. Globalization emanates from policies in different domains including transport, trade (import and export), finance, migration, politics, etc. The N11 countries should be more financially integrated into the world economy. The governments of the N11 countries should support financial and trade liberalization, that is, the political structure should encourage more inflows of foreign capitals and technologies. However, these foreign funds and technologies are to be invested/used in green production processes. The various dimensions of globalization should be taken into consideration when enacting environmental sustainability policies.

In countries like Bangladesh, S/Korea, Nigeria, Indonesia, and Turkey where natural resources decline environmental quality, there is a need to imbibe sustainable practices into the countries resource exploration. The increasing impact of financial development on the EF shows the weakness in countries financial institutions to direct financial investments in less-polluting ventures. The financial system needs to be strengthened to encourage investment in less-polluting sectors and clean technologies. The negative influence of urbanization on human well-being calls for the adequate provision of infrastructures and basic amenities in the rural areas which will not only curtail the upward surge in urbanization and its anomaly but also promote economic and environmental sustainability. Finally, since urbanization is found to be associated with environmental degradation via increasing the $\mathrm{EF}$, the $\mathrm{N} 11$ countries should redesign their urbanization policies to make urbanization more sustainable. As such, the government should facilitate the sustainable transformation of the production and consumption practices within the urban areas. Urban sustainability could be achieved through the promotion of green housing projects and green transportation in urban areas. Developing environmentally friendly technologies is also imperative for minimizing the adverse environmental impacts of urbanization in the N11 countries.

This study considered just eleven countries. Also, the time period was limited to just 27 years and some determinants of human well-being were not considered all due to data constraint, hence the limitations of the study. Besides, although an improvement over just using income to measure well-being, the HDI has a number of internal inconsistencies that make it problematic to 
use to determine whether the well-being of a country's citizens has really improved or not. For instance, the index (HDI) does not include any ecological considerations, rather focuses almost exclusively on national performance and ranking, without much attention to development from a global perspective [63]. Now, the future study may want to explore the interactive effect of institutional quality and inequality on both sustainability indicators within the vicinity of a more robust estimation technique(s) by extending the sample to include more developing countries for a more meaningful study.

\section{Appendix}

See Figs. 6, 7, and 8.

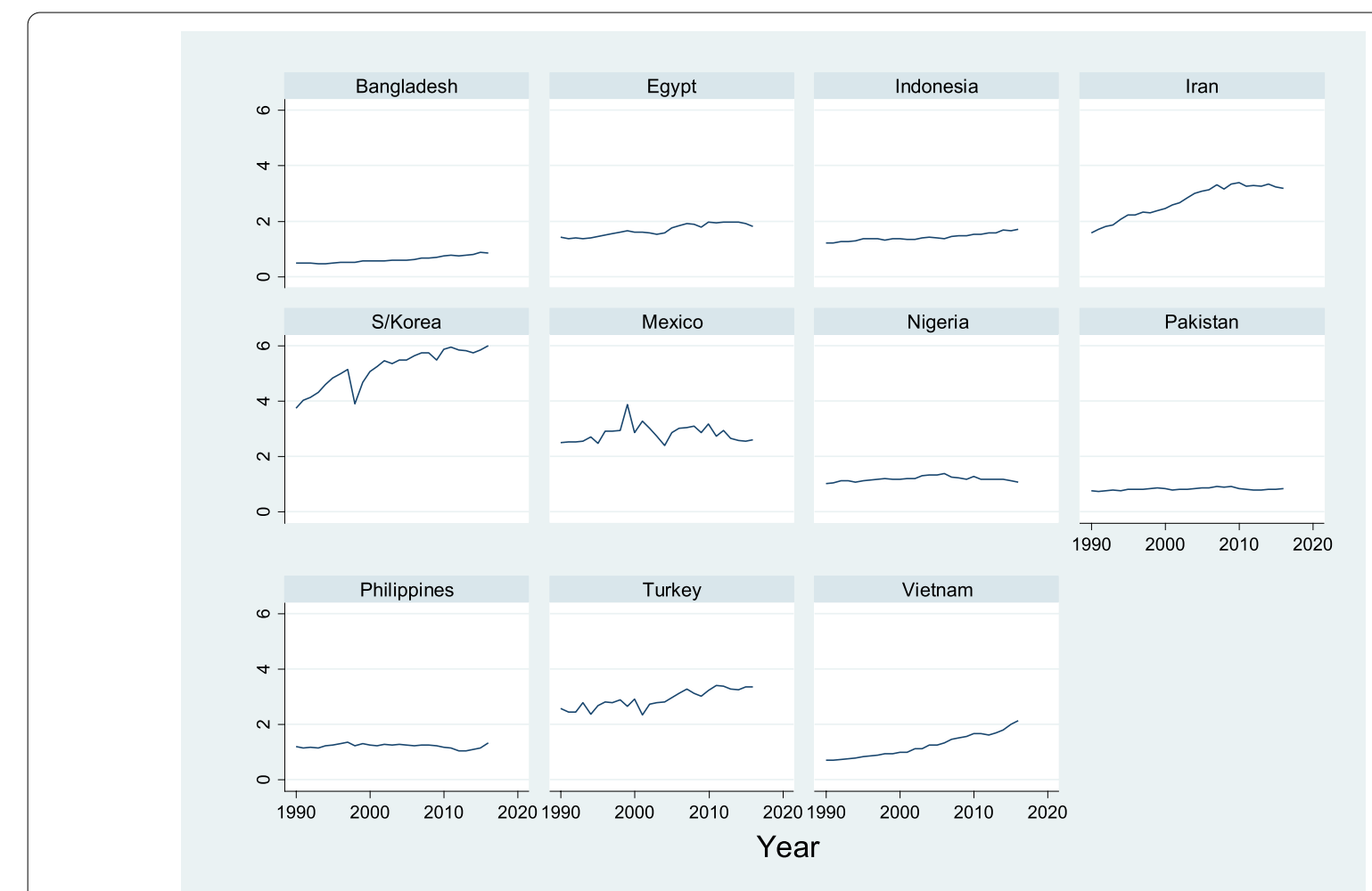

Fig. $6 \mathrm{EF}$ in the individual N11 countries 


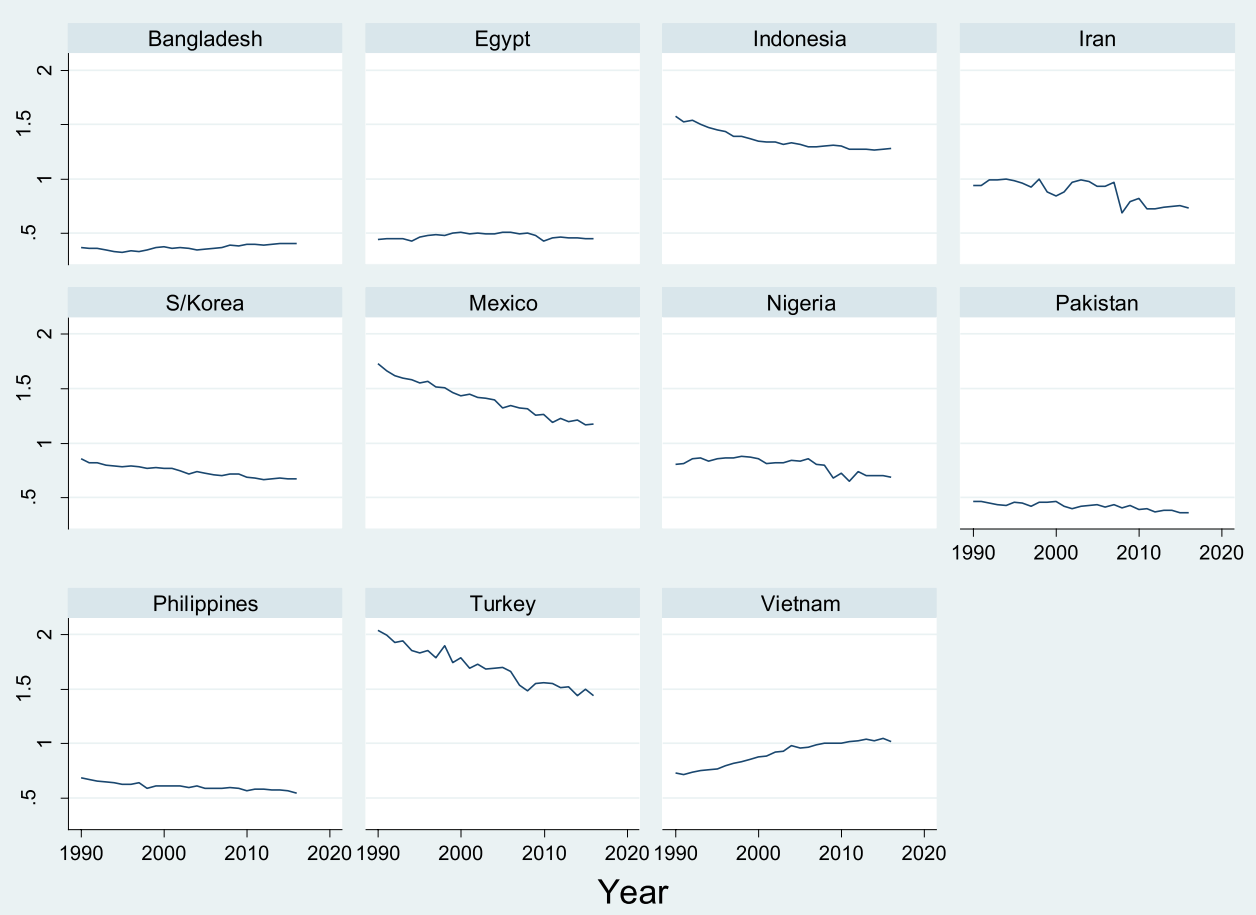

Fig. 7 Biocapacity in the individual N11 countries

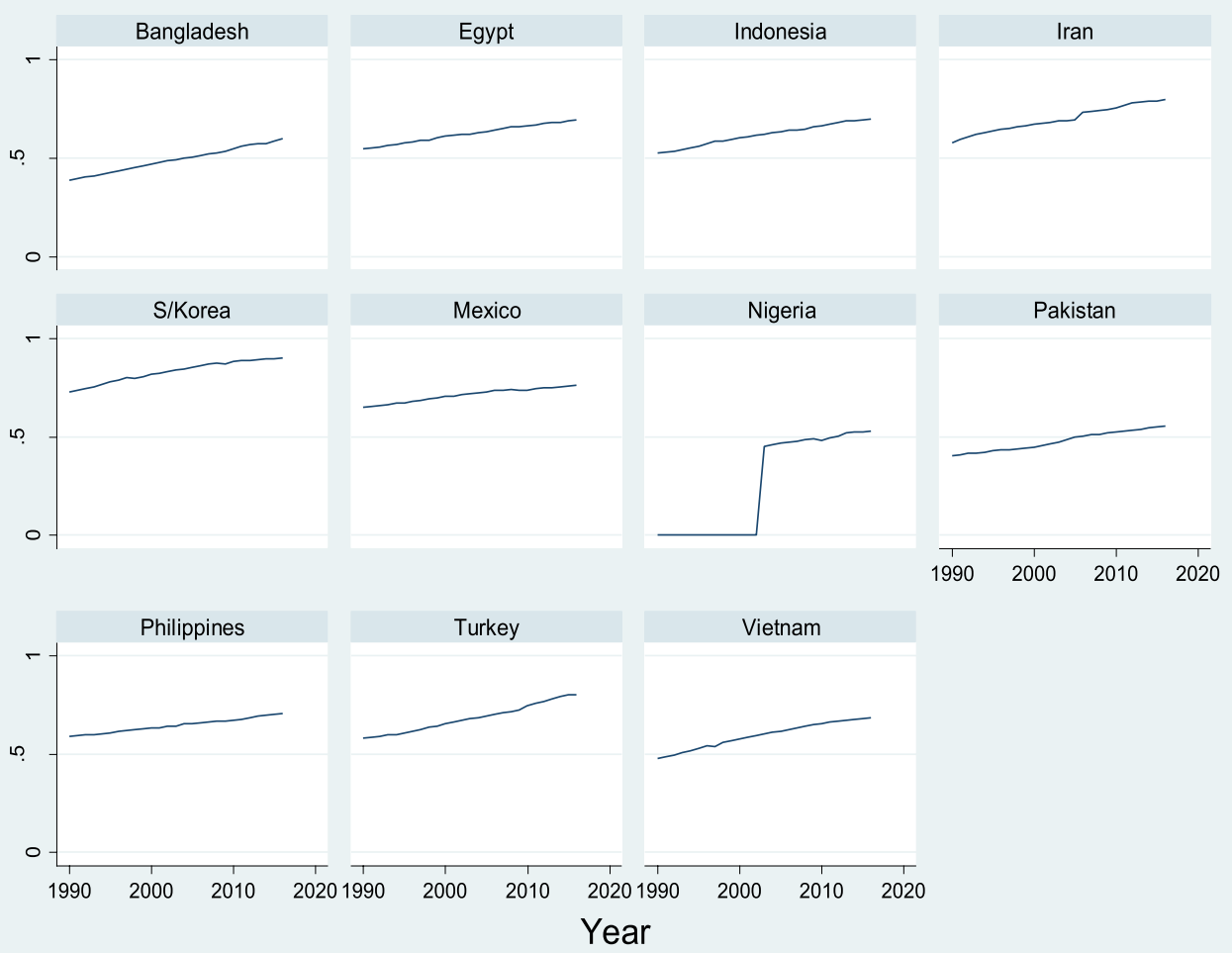

Fig. $8 \mathrm{HDI}$ in the individual N11 countries 


\section{Abbreviations}

N11: Eleven fastest emerging economies; CD: Cross-sectional dependence; EF: Ecological footprint; AMG: Augmented mean group; MEA: Millennium Ecosystem Assessment; SDGs: Sustainable development goals; DH: Dumitrescu and Hurlin; OBOR: One-belt-one-road; FGLS: Feasible generalized least squares; DK Driscoll and Kraay; PCSE: Panel-corrected standard errors; HDI: Human development index; PMG: Pooled mean group; CIPS: Cross-sectionally augmented IPS; CS-ARDL: Cross-sectionally augmented autoregressive distributed lag; CADF: Cross-sectionally augmented ADF.

\section{Acknowledgements}

The author expresses his gratitude to the anonymous reviewers for their efforts in reviewing the paper and suggesting key modifications that have enhanced the quality of the article. The author also thanks the editor for his cooperation during the review process.

\section{Authors' contributions}

The study was solely carried out by the corresponding author.

\section{Funding}

No funding was received for this study.

\section{Availability of data and materials}

The datasets used and/or analyzed during the current study are available from the corresponding author on reasonable request.

\section{Declaration}

\section{Competing interests}

The author declares no competing interest.

\section{Author details}

${ }^{1}$ Department of Economics, University of Lagos, Akoka, Nigeria. ${ }^{2}$ School of Foundation, Lagos State University, Badagry, Nigeria.

Received: 3 November 2020 Accepted: 26 April 2021

Published: 7 July 2021

\section{References}

1. Acheampong AO, Adams S, Boateng E (2019) Do globalization and renewable energy contribute to carbon emissions mitigation in SubSaharan Africa? Sci Total Environ 677:436-446

2. Adedoyin FF, Nathaniel S, Adeleye N (2021) An investigation into the anthropogenic nexus among consumption of energy, tourism, and economic growth: do economic policy uncertainties matter? Environ Sci Pollut Res 28(3):2835-2847

3. Ahmad M, Jiang P, Murshed M, Shehzad K, Akram R, Cui L, Khan Z (2021) Modelling the dynamic linkages between eco-innovation, urbanization, economic growth and ecological footprints for G7 countries: does financial globalization matter? Sustain Cities Soc 70:102881

4. Ahmed Z, Asghar MM, Malik MN, Nawaz K (2020) Moving towards a sustainable environment: the dynamic linkage between natural resources, human capital, urbanization, economic growth, and ecological footprint in China. Resour Policy 67:101677

5. Ahmed Z, Cary M, Le HP (2021) Accounting asymmetries in the long-run nexus between globalization and environmental sustainability in the United States: an aggregated and disaggregated investigation. Environ Impact Assess Rev 86:106511

6. Ahmed Z, Nathaniel SP, Shahbaz M (2021) The criticality of information and communication technology and human capital in environmental sustainability: evidence from Latin American and Caribbean countries. J Clean Prod 286:125529

7. Ahmed Z, Zafar MW, Ali S (2020) Linking urbanization, human capital, and the ecological footprint in G7 countries: an empirical analysis. Sustain Urban Areas 55:102064

8. Ali R, Bakhsh K, Yasin MA (2019) Impact of urbanization on CO2 emissions in emerging economy: evidence from Pakistan. Sustain Urban Areas 48:101553
9. Ansari MA, Haider S, Khan NA (2020) Environmental Kuznets curve revisited: an analysis using ecological and material footprint. Ecol Ind 115:106416

10. Baloch MA, Zhang J, lqbal K, lqbal Z (2019) The effect of financial development on ecological footprint in BRI countries: evidence from panel data estimation. Environ Sci Pollut Res 26(6):6199-6208

11. Banerjee S, Murshed M (2020) Do emissions implied in net export validate the pollution haven conjecture? Analysis of G7 and BRICS countries. Int J Sustain Econ 12(3):297-319

12. Biggeri M, Mauro V (2018) Towards a more'sustainable' human development index: integrating the environment and freedom. Ecol Ind 91:220-231

13. Biggeri M, Clark DA, Ferrannini A, Mauro V (2019) Tracking the SDGs in an 'integrated' manner: a proposal for a new index to capture synergies and trade-offs between and within goals. World Dev 122:628-647

14. Bond S, Eberhardt M (2013) Accounting for unobserved heterogeneity in panel time series models. University of Oxford, Oxford

15. Cerutti AK, Beccaro GL, Bruun S, Donno D, Bonvegna L, Bounous G (2016) Assessment methods for sustainable tourism declarations: the case of holiday farms. J Clean Prod 111:511-519

16. Cheng Z, Li L, Liu J (2020) Natural resource abundance, resource industry dependence and economic green growth in China. Resour Policy 68:101734

17. Costanza R, Kubiszewski I, Giovannini E, Lovins H, McGlade J, Pickett KE, Ragnarsdóttir KV, Roberts D, De Vogli R, Wilkinson R (2014) Development: time to leave GDP behind. Nat News 505(7483):283

18. Danish, Ulucak R, Khan SU (2020) Determinants of the ecological footprint: role of renewable energy, natural resources, and urbanization. Sustain Cities Soc 54:101996

19. Dogan E, Ulucak R, Kocak E, Isik C (2020) The use of ecological footprint in estimating the Environmental Kuznets Curve hypothesis for BRICST by considering cross-section dependence and heterogeneity. Sci Total Environ 723:138063-138063

20. Dumitrescu El, Hurlin C (2012) Testing for Granger non-causality in heterogeneous panels. Econ Model 29(4):1450-1460

21. El-Deeb MS, Halim YT (2020) Using Ecological Footprint Accounting model as a tool for sustainable development in the hospitality industry: evidence from Egypt. Account J 24(2):564-602. https://doi.org/10.21608/ ATASU.2020

22. Erdoğan S, Çakar ND, Ulucak R, Kassouri Y (2021) The role of natural resources abundance and dependence in achieving environmental sustainability: evidence from resource-based economies. Sustain Dev 29(1):143-154

23. Fernández M, Alférez A, Vidal S, Fernández MY, Albareda S (2016) Methodological approaches to change consumption habits of future teachers in Barcelona, Spain: reducing their personal Ecological Footprint. J Clean Prod 122:154-163

24. GFN (2019) Ecological Footprint per Person of Country's Population (in global hectares). https://data.footprintnetwork.org/\#/ Accessed 1st May 2019

25. Global Footprint Network (2019) Advancing the science of sustainability. http://data.footprintnetwork.org/?_ga=2.128662604.1393481519.15895 55821-401373056.1547219594\#/countryTrends?type=BCtot,EFCtot\&cn= 351. Accessed 1 June 2019

26. Guan J, Kirikkaleli D, Bibi A, Zhang W (2020) Natural resources rents nexus with financial development in the presence of globalization: is the "resource curse" exist or myth? Resour Policy 66:101641

27. Hassan ST, Baloch MA, Mahmood N, Zhang J (2019) Linking economic growth and ecological footprint through human capital and biocapacity. Sustain Urban Areas 47:101516

28. Hassan ST, Xia E, Khan NH, Shah SMA (2019) Economic growth, natural resources, and ecological footprints: evidence from Pakistan. Environ Sci Pollut Res 26(3):2929-2938

29. International Monetary Fund (IMF) (2016) Introducing a new broad-based index of financial development, IMF Working Paper WP/16/5. http://data. imf.org/?sk1/4F8032E80-B36C-43B1-AC26-493C5B1CD33B. Accessed 1 Aug 2019

30. lorember PT, Goshit GG, Dabwor DT (2020) Testing the nexus between renewable energy consumption and environmental quality in Nigeria: the role of broad-based financial development. Afr Dev Rev 32(2):163-175 
31. Kassouri Y, Altıntaş H (2020) Human well-being versus ecological footprint in MENA countries: a trade-off? J Environ Manag 263:110405

32. Khalid K, Usman M, Mehdi MA (2021) The determinants of environmental quality in the SAARC region: a spatial heterogeneous panel data approach. Environ Sci Pollut Res 28(6):6422-6436

33. Khan Z, Hussain M, Shahbaz M, Yang S, Jiao Z (2020) Natural resource abundance, technological innovation, and human capital nexus with financial development: a case study of China. Resour Policy 65:101585

34. Kirikkaleli D, Adebayo TS, Khan Z, Ali S (2021) Does globalization matter for ecological footprint in Turkey? Evidence from dual adjustment approach. Environ Sci Pollut Res 28(11):14009-14017

35. KOF (2017) KOF index of globalization [WWW Document]. https://www kof.ethz.ch/en/forecasts-and-indicators/indicators/kof-globalisationindex.html. Accessed: 5 July 2020

36. Kongbuamai N, Bui Q, Yousaf HMAU, Liu Y (2020) The impact of tourism and natural resources on the ecological footprint: a case study of ASEAN countries. Environ Sci Pollut Res 27(16):19251-19264

37. Kurniawan R, Managi S (2018) Coal consumption, urbanization, and trade openness linkage in Indonesia. Energy Policy 121:576-583

38. Lashitew AA, Werker E (2020) Do natural resources help or hinder development? Resource abundance, dependence, and the role of institutions. Resour Energy Econ 61:101183

39. Liu M, Ren X, Cheng C, Wang Z (2020) The role of globalization in CO2 emissions: a semi-parametric panel data analysis for G7. Sci Total Environ 718:137379

40. Long $X$, Yu H, Sun M, Wang XC, Klemeš JJ, Xie W, Wang C, Li W, Wang Y (2020) Sustainability evaluation based on the three-dimensional Ecological Footprint and Human Development Index: a case study on the four island regions in China. J Environ Manag 265:110509

41. Millennium Ecosystem Assessment (2005) Ecosystems and human wellbeing. https://www.millenniumassessment.org/documents/document. 358.aspx.pdf. Accessed 10 Dec 2019

42. Murshed M, Alam R, Ansarin A (2021) The environmental Kuznets curve hypothesis for Bangladesh: the importance of natural gas, liquefied petroleum gas, and hydropower consumption. Environ Sci Pollut Res 28(14):17208-17227

43. Murshed M, Ali S, Haseeb M, Nathaniel SP (2021) Modelling the public moral hazard problem of international remittance inflows in Bangladesh. Int J Sustain Econ 13(2):1

44. Murshed M, Haseeb M, Alam MS (2021) The Environmental Kuznets Curve hypothesis for carbon and ecological footprints in South Asia: the role of renewable energy. Geo Journal 1-28

45. Nathaniel SP (2020) Ecological footprint, energy use, trade, and urbanization linkage in Indonesia. GeoJournal 1-14

46. Nathaniel SP (2021) Environmental degradation in ASEAN: assessing the criticality of natural resources abundance, economic growth and human capital. Environ Sci Pollut Res 1-13

47. Nathaniel SP, Adeleye N (2021) Environmental preservation amidst carbon emissions, energy consumption, and urbanization in selected African countries: implication for sustainability. J Clean Prod 285:125409

48. Nathaniel SP, Bekun F, Faizulayev A (2021) Modelling the impact of energy consumption, natural resources, and urbanization on ecological footprint in South Africa: assessing the moderating role of human capital. Int J Energy Econ Policy 11(3):130-139

49. Nathaniel SP, Nwulu N, Bekun F (2021) Natural resource, globalization, urbanization, human capital, and environmental degradation in Latin American and Caribbean countries. Environ Sci Pollut Res 28(5):6207-6221

50. Nathaniel SP, Yalçiner K, Bekun FV (2020) Assessing the environmental sustainability corridor: linking natural resources, renewable energy, human capital, and ecological footprint in BRICS. Resour Policy 70:101924

51. Nathaniel S, Khan S (2020) Public health financing, environmental quality, and the quality of life in Nigeria. J Public Aff 20:e2103

52. Nathaniel S, Anyanwu O, Shah M (2020) Renewable energy, urbanization, and ecological footprint in the Middle East and North Africa region. Environ Sci Pollut Res 1-13

53. Nathaniel S, Nwodo O, Sharma G, Shah M (2020) Renewable energy, urbanization, and ecological footprint linkage in CIVETS. Environ Sci Pollut Res 27(16):19616-19629
54. Nathaniel SP, Barua S, Ahmed Z (2021) What drives ecological footprint in top ten tourist destinations? Evidence from advanced panel techniques. Environ Sci Pollut Res. https://doi.org/10.1007/s11356-021-13389-5

55. Omojolaibi J, Nathaniel SP (2020) Assessing the potency of environmental regulation in maintaining environmental sustainability in MENA countries: an advanced panel data estimation. J Public Affairs e2526

56. Panayotou T (1993) Empirical tests and policy analysis of environmental degradation at different stages of economic development (No. 992927783402676). International Labour Organization

57. Pandey S, Dogan E, Taskin D (2020) Production-based and consumptionbased approaches for the energy-growth-environment nexus: evidence from Asian countries. Sustain Prod Consump 23:274-281

58. Pata UK (2021) Renewable and non-renewable energy consumption, economic complexity, CO 2 emissions, and ecological footprint in the USA: testing the EKC hypothesis with a structural break. Environ Sci Pollut Res 28(1):846-861

59. Pata UK, Caglar AE (2021) Investigating the EKC hypothesis with renewable energy consumption, human capital, globalization and trade openness for China: evidence from augmented ARDL approach with a structural break. Energy 216:119220

60. Pesaran HM (2004) General diagnostic tests for cross-section dependence in panels. Fac Econ. https://doi.org/10.17863/CAM.5113

61. Pesaran MH (2007) A simple panel unit root test in the presence of crosssection dependence. J Appl Econ 22:265-312

62. Rongwei X, Xiaoying Z (2020) Is financial development hampering or improving the resource curse? New evidence from China. Resour Policy 67:101676

63. Sagar AD, Najam A (1998) The human development index: a critical review. Ecol Econ 25(3):249-264

64. Sahay R, Čihák M, N'diaye P, Barajas A, Bi R, Ayala D, Gao Y, Kyobe A, Nguyen L, Svirydzenka K (2015) Rethinking financial deepening: stability and growth in emerging markets. IMF Staff Discussion Note. International Monetary Fund

65. Sarkodie SA, Adams S (2020) Electricity access, human development index, governance and income inequality in Sub-Saharan Africa. Energy Rep 6:455-466

66. Saud S, Chen S, Haseeb A (2020) The role of financial development and globalization in the environment: accounting ecological footprint indicators for selected one-belt-one-road initiative countries. J Clean Prod 250:119518

67. Shahbaz M, Balsalobre D, Shahzad SJH (2019) The influencing factors of $\mathrm{CO} 2$ emissions and the role of biomass energy consumption: statistical experience from G-7 countries. Environ Model Assess 24(2):143-161

68. Sharif A, Baris-Tuzemen O, Uzuner G, Ozturk I, Sinha A (2020) Revisiting the role of renewable and non-renewable energy consumption on Turkey's ecological footprint: evidence from Quantile ARDL approach. Sustain Urban Areas 57:102138

69. Sharma R, Sinha A, Kautish P (2021) Does financial development reinforce environmental footprints? Evidence from emerging Asian countries. Environ Sci Pollut Res 28(8):9067-9083

70. Sinha A, Sengupta T (2019) Impact of natural resource rents on human development: what is the role of globalization in Asia Pacific countries? Resour Policy 63:101413

71. Sinha A, Sengupta T, Alvarado R (2020) Interplay between technological innovation and environmental quality: formulating the SDG policies for next 11 economies. J Clean Prod 242:118549

72. Solarin SA, Nathaniel SP, Bekun FV, Okunola AM, Alhassan A (2021) Towards achieving environmental sustainability: environmental quality versus economic growth in a developing economy on ecological footprint via dynamic simulations of ARDL. Environ Sci Pollut Res 28(14):17942-17959

73. Sun Y, Ak A, Serener B, Xiong D (2020) Natural resource abundance and financial development: a case study of emerging seven ( $E-7)$ economies. Resour Policy 67:101660

74. Ulucak R, Bilgili F (2018) A reinvestigation of EKC model by ecological footprint measurement for high, middle and low income countries. J Clean Prod 188:144-157

75. UNDP (2011) Sustainability and equity: a better future for all, Human Development Report 2011. https://doi.org/10.2307/2137795

76. UNDP (2017) Human development report 2017. United Nations Dev. Program, 12 Jan 2019. http://hdr.undp.org/en/data 
77. Usman M, Khalid K, Mehdi MA (2021) What determines environmental deficit in Asia? Embossing the role of renewable and non-renewable energy utilization. Renew Energy 168:1165-1176

78. Wang Z, Bui Q, Zhang B, Pham TLH (2020) Biomass energy production and its impacts on the ecological footprint: an investigation of the $\mathrm{G} 7$ countries. Sci Total Environ 743:140741

79. Westerlund J (2007) Error correction based panel cointegration tests. Oxf Bull Econ Stat 69:709-748

80. Winoto J, Schultink G (1996) Impacts of urbanization on agricultural sustainability and rural life in West Java, Indonesia. Research report from the Michigan State University Agricultural Experiment Station, East Lansing

81. World Development Indicator (WDI) (2019). World Bank Development Indicators database (online) available at https://data.worldbank.org/. Accessed 24 Oct 2019

82. Yang B, Jahanger A, Ali M (2021b) Remittance inflows affect the ecological footprint in BICS countries: do technological innovation and financial development matter? Environ Sci Pollut Res 1-19

83. Yang $B$, Jahanger $A$, Usman $M$, Khan MA (2021) The dynamic linkage between globalization, financial development, energy utilization, and environmental sustainability in GCC countries. Environ Sci Pollut Res 147(2):621-649

84. Yasin I, Ahmad N, Chaudhary MA (2020) Catechizing the environmentalimpression of urbanization, financial development, and political institutions: a circumstance of ecological footprints in 110 developed and less-developed countries. Soc Indic Res 147(2):621-649

85. Zafar MW, Zaidi SAH, Khan NR, Mirza FM, Hou F, Kirmani SAA (2019) The impact of natural resources, human capital, and foreign direct investment on the ecological footprint: the case of the United States. Resour Policy 63:101428

86. Zafar MW, Zaidi SAH, Sinha A, Gedikli A, Hou F (2019) The role of stock market and banking sector development, and renewable energy consumption in carbon emissions: insights from G-7 and N-11 countries. Resour Policy 62:427-436

87. Zaidi SAH, Zafar MW, Shahbaz M, Hou F (2019) Dynamic linkages between globalization, financial development and carbon emissions: evidence from Asia Pacific Economic Cooperation countries. J Clean Prod 228:533-543

88. Zhang L, Godil DI, Bibi M, Khan MK, Sarwat S, Anser MK (2021) Caring for the environment: how human capital, natural resources, and economic growth interact with environmental degradation in Pakistan? A dynamic ARDL approach. Sci Total Environ 774:145553

89. Zhou Y, Li Y, Liu Y (2020) The nexus between regional eco-environmental degradation and rural impoverishment in China. Habitat Int 96:102086

\section{Publisher's Note}

Springer Nature remains neutral with regard to jurisdictional claims in published maps and institutional affiliations.

\section{Submit your manuscript to a SpringerOpen ${ }^{\circ}$ journal and benefit from:}

- Convenient online submission

$\checkmark$ Rigorous peer review

- Open access: articles freely available online

- High visibility within the field

Retaining the copyright to your article

Submit your next manuscript at $\boldsymbol{\nabla}$ springeropen.com 